University of Tulsa College of Law

TU Law Digital Commons

Articles, Chapters in Books and Other Contributions to Scholarly Works

2013

\title{
Are Legal Ethics Ethical? A Survey Experiment
}

Stephen Galoob

$\mathrm{Su} \mathrm{Li}$

Follow this and additional works at: http://digitalcommons.law.utulsa.edu/fac_pub

Part of the Legal Ethics and Professional Responsibility Commons

\section{Recommended Citation}

26 Geo. J. Legal Ethics 481 (2013).

This Article is brought to you for free and open access by TU Law Digital Commons. It has been accepted for inclusion in Articles, Chapters in Books and Other Contributions to Scholarly Works by an authorized administrator of TU Law Digital Commons. For more information, please contact daniel-bell@utulsa.edu. 


\title{
Are Legal Ethics Ethical? A Survey Experiment
}

\author{
STEPHEN R. GalOOB* AND SU LI**
}

\begin{abstract}
Many core questions in legal ethics concern the relationship between ordinary morality and rules of professional conduct that govern lawyers. Do these legal ethics rules diverge from ordinary morality? Is the lawyer's role morally distinctive? Do professional norms establish what the lawyer has most reason to do? Conjectured answers to these questions abound. In this Article, we use methods from moral psychology and experimental philosophy to provide the first systematic, empirical examination of these questions. Results from a survey experiment suggest that legal ethics rules about advocacy and confidentiality diverge from lay moral judgments; that lay judgments do not, in general, attribute distinctive moral significance to the lawyer's role; and that norms of professional conduct can change (but do not fully determine) the ordinary moral status of lawyers' actions. We conclude by discussing some theoretical and policy implications of these results.
\end{abstract}

\section{TABLE OF CONTENTS}

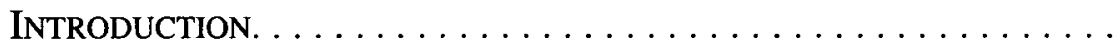

I. Three Empirical Questions About Legal Ethics . . . . . . . .

A. DO LEGAL ETHICS RULES DIVERGE FROM ORDINARY

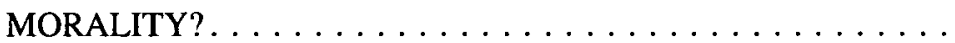

B. HOW MUCH DOES THE LAWYER'S ROLE MATTER

MORALLY? .....................

* Ph.D. Candidate, Program in Jurisprudence and Social Policy, School of Law, University of California, Berkeley; (beginning fall 2013) Assistant Professor of Law, University of Tulsa College of Law. We are grateful to participants at a panel on Comparative Legal Ethics at the 2012 meeting of the Law and Society Association and an audience at the 2012 Conference on Empirical Legal Studies for feedback. Special thanks to John Bliss, Steve Bundy, David Fontana, Michael Gilbert, Patrick Hanlon, Adam Hill, Daniel Ho, Sung Hui Kim, Christopher Kutz, Robert Lawless, Ethan Leib, Rob MacCoun, Joy Milligan, Victoria Plaut, Kevin Quinn, Keramet Reiter, Deborah Rhode, Naomi Schoenbaum, Bill Simon, Christina Stevens, the JSP working group, participants in the interdisciplinary seminar on moral psychology at U.C. Berkeley's Townsend Center for the Humanities, and the staff of the Experimental Psychology Laboratory at U.C. Berkeley (including Miho Tanaha and Rowlima del Castillo). This research was supported by a grant from the Alumni Fund of the Jurisprudence and Social Policy Program at the U.C. Berkeley School of Law. (O) 2013, Stephen R. Galoob and Su Li.

** Statistician, Center for the Study of Law \& Society, University of California, Berkeley. 
C. DO PROFESSIONAL NORMS DETERMINE THE LAWYER'S

REASONS? . . . . . . . . . . . . . . . . .

II. Data ANd Methodology . . . . . . . . . . . . . . . . . . . . . 497

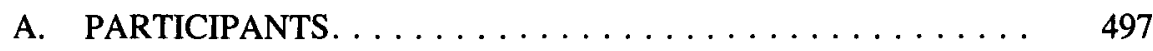

B. EXPERIMENTAL PROCEDURES $\ldots \ldots \ldots \ldots \ldots \ldots \ldots .498$

C. MATERIALS ..................... 498

III. RESULTS . . . . . . . . . . . . . . . . . . . . . . 501

A. DIVERGENCE AND CONVERGENCE . . . . . . . . 501

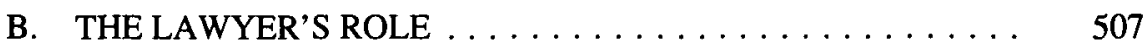

C. PROFESSIONAL NORMS . . . . . . . . . . . . . . 509

IV. IMPLICATIONS AND FutURE RESEARCH $\ldots \ldots \ldots \ldots \ldots \ldots \quad 511$

APPENDIX 1: AfFECTIVE MANIPUlations AND RESUlts . . . . . . 515

\section{INTRODUCTION}

Consider three central questions in contemporary debates about professional responsibility. The first question concerns divergence: does the law governing lawyers permit or require a lawyer to act in ways that deviate from ordinary morality? Divergence is a long-discussed issue, one perhaps as old as the legal profession itself. For example, Michel de Montaigne's conclusion that "an honest man is not accountable for the vice or stupidity of his trade, and should not therefore refuse to practice it" is premised on the notion that there is "knavery" in the lawyer's calling. ${ }^{1}$ Yet this premise is controversial. Some contend that legal ethics rules diverge from ordinary morality. Others argue that there is no divergence, and thus (contra Montaigne) deny that the lawyer's calling essentially involves knavery. Resolving this question is central to theoretical efforts to justify lawyers' professional actions, many of which concern (in Charles Fried's phrase) whether "a good lawyer [can] be a good person."2

A second question concerns distinctiveness: does the lawyer's role matter as such in determining the moral status of the lawyer's action? Perhaps the lawyer's

1. Michel de Montaigne, Of Husbanding Your Will, in The Complete Works of MontaIGNe 774 (Donald M. Frame trans., 1958).

2. Charles Fried, The Lawyer as Friend: The Moral Foundations of the Lawyer-Client Relation, 85 YALE L.J. 1060,1060 (1976). 
role gives her exceptional moral prerogatives and responsibilities, ones that do not apply to incumbents of other professional roles. On the other hand, perhaps the lawyer's role does not and cannot make this kind of moral difference. On these issues, too, conjectures abound. As a sociological matter, the unique normative significance of the lawyer's role is among "the legal profession's most important constitutive beliefs." 3 Many theoretical arguments and policy debates about legal ethics also presuppose that the lawyer's role is unique. Yet there have been no attempts to verify empirically whether the lawyer's professional role has any special moral significance, let alone whether it is uniquely significant.

A third question concerns the significance of professional norms: how do the rules governing lawyers affect the moral status of an individual lawyer's actions? This question is salient for the lawyer who is deciding what to do in a particular case. A variety of sources might inform this practical deliberation. The lawyer could decide what to do by consulting the broad values (like the promotion of justice and the protection of rights) that animate the legal profession. She might instead consult generally applicable moral principles or values, such as those prohibiting the infliction of harm or degradation of others. Or she might follow the professional norms and rules that apply to lawyers in her jurisdiction. If all of these sources support the same action, then the answer seems obvious: the lawyer should act in the way favored by morality, professional values, and professional norms. However, this practical question is more perplexing when the various sources point in different directions. Local professional norms might deviate from the broader values that animate the legal profession. Likewise, professional norms and professional values might coincide but nevertheless conflict with broader moral requirements. How should the lawyer resolve these practical conflicts in deciding what to do? Do professional norms trump professional values and moral values?

Many commentators on professional responsibility presume to know the "correct" answers to the questions of divergence, distinctiveness, and the significance of professional norms. These presumptions lack empirical support. We provide the first rigorous empirical examination of these central questions. Utilizing a survey-experiment methodology common in moral psychology and experimental philosophy, we examine divergence by comparing how lay judgments and legal ethics rules classify specific actions. We examine distinctiveness by isolating whether lay judgments attribute a distinctive (and unique) significance to the lawyer's professional role. We assess the significance of professional norms by gauging their influence on lay judgments about the moral status of lawyers' actions. In short, our experimental methodology tests crucial issues in legal ethics that have heretofore only been conjectured.

3. David B. Wilkins, Making Context Count: Regulating Lawyers After Kaye, Scholer, 66 S. CAL. L. REV. $1145,1148-9$ (1993). 
This Article has four parts. Part I explores three empirically informed questions about legal ethics and identifies several verifiable hypotheses. Part II describes a survey experiment we used to collect data that tests these hypotheses. We analyze these data in Part III. Our findings suggest that many legal ethics rules (even some that are controversial among legal ethicists) accord with lay moral judgments about particular cases. However, some central rules regarding advocacy and confidentiality appear to be at odds with lay moral judgments. Our findings also suggest that lay judgments do not generally attribute distinctive moral significance to the lawyer's professional role, although the lawyer's role appears to make a moral difference regarding conflicts of interest. Finally, our findings suggest that the professional norms governing lawyers affect (but do not fully determine) lay moral judgments about lawyers' professional actions. In Part IV, we discuss some implications of these findings and areas for future research.

\section{Three EMPIRICAL Questions About Legal EThICS}

In this Part, we examine three open, empirically informed questions about legal ethics and ordinary morality. From our examination of these questions, we derive a series of testable claims about legal ethics.

Throughout, we use the term "ordinary morality" in the empirical, pretheoretic sense that many psychologists and some philosophers do: as the set of judgments that would be arrived at by consulting operative moral principles, or the principles that "actually operat[e]" in a person's "exercise of moral judgment." We use the terms "ordinary moral judgments," "empirical moral judgments," and "lay judgments" synonymously to refer to judgments within this set.

\section{A. DO LEGAL ETHICS RULES DIVERGE FROM ORDINARY MORALITY?}

One of the most contested questions in legal ethics is whether the rules governing the professional conduct of lawyers cohere with ordinary morality. We will say that the rules of legal ethics diverge from ordinary morality if the former provide a different verdict about the deontic status of an action than do the latter. ${ }^{5}$ By "deontic status," we mean whether an action is classified as forbidden, "merely" permissible (i.e., optional), or required. By contrast, the rules of legal

\footnotetext{
4. John M. Mikhail, Elements of Moral Cognition: Rawls' Linguistic Analogy and the Cognittve SCIENCE OF MORAL AND LEGAL JUdGMENT 19 (2011).

5. Classification is only one possible area in which the questions of divergence and convergence arise. Legal ethics might also diverge from ordinary morality in the epistemic burdens that lawyers have, see William Edmundson, Contextualist Answers to Skepticism, and What a Lawyer Cannot Know, 30 FLA. ST. U. L. Rev. 1, 3 (2002), or the attitudes that lawyers are encouraged to take towards the performance of ordinarily immoral actions, see Richard K. Greenstein, Against Professionalism, 22 Geo. J. LeGAL ETHICs 327, 352-56 (2009).
} 
ethics and ordinary morality would converge if both schema offer the same verdict on the status of an action.

Every substantive theory of legal ethics rests on empirical claims about divergence and convergence, although these claims serve different functions in different theories. For some theories, the justification of a legal ethics rule is a function of whether the rule converges with broader normative principles. ${ }^{6}$ According to these views, facts about convergence and divergence directly determine whether a legal ethics rule is justified. On the other hand, some legal ethics theories deny that broader normative considerations are directly relevant (or relevant at all) to evaluating rules of legal ethics. Yet, even on these views, empirical claims about divergence and convergence do important analytic work. ${ }^{7}$ Our goal here is not to directly resolve which of these substantive theories is best, nor to establish whether legal ethics rules should diverge from or converge with ordinary morality. Rather, our inquiry concerns the prior question of whether legal ethics rules do diverge from or converge with ordinary morality.

There are at least three aspects to an empirical assessment of the connection between legal ethics and ordinary morality. The first is whether legal ethics rules and ordinary morality reach different verdicts about specific actions. Divergence would be realized if ordinary morality forbids an action that legal ethics rules permit or require; if an action were required as a matter of ordinary morality, but forbidden or optional under legal ethics rules; or if an action were optional as a matter of ordinary morality, but forbidden or required by rules of legal ethics. By contrast, legal ethics and ordinary morality converge if both schema reach the same verdict on the status of an action. The empirical case for convergence might be made generally, on the argument that "operative legal principles exist because they more or less adequately capture an intuitive sense of justice." ${ }^{8}$ This logic suggests that, where rules of legal ethics are sufficiently widespread, they should overlap with ordinary moral judgments. Others make the case for convergence more directly by arguing that specific principles of legal ethics replicate ordinary

6. See generally David Luban, Legal Ethics and Human Dignty (2007) [hereinafter Luban, Legal ETHICS and Human DigntTy]; Deborah Rhode, In the InTERests of Justice: Reforming the Legal Profession (2003) [hereinafter Rhode, In the Interests of Justice]; William H. Simon, The Practice of Justice (1998).

7. For example, Tim Dare's defense of the "standard conception" of the lawyer's role assumes that empirical divergence exists, but denies that this divergence affects the justification of legal ethics rules or regimes. TIM Dare, The counsel of Rogues?: A Defence of THE Standard Conception of the Lawyer's Role 12-25 (2009). Daniel Markovits takes divergence as a premise in his vindication of an ethos of lawyering based on distinctively "lawyerly virtues." See DANIEL MARKovits, A MODERN LEGAL ETHICS: AdVERSARY AdVOCACY IN A DEmoCRATIC AGE $\S 2$ (2008). Likewise, W. Bradley Wendel's legitimacy-based account of the lawyer's professional responsibilities presumes that legal ethics do not systematically or significantly diverge from ordinary morality. See W. Bradley Wendel, Professional Roles and Moral Agency, 89 GEO. L.J. 667, 688 (2001).

8. Jonathan Cohen \& Joshua Greene, For the Law, Neuroscience Changes Nothing and Everything, 359 Phil. Transactional of THE Royal. Soc'y B. 1775 (2004). 
moral principles. ${ }^{9}$ The claim here is that legal ethics rules classify the lawyer's actions in a way that roughly conforms to the classification in ordinary morality.

If legal ethics diverge from ordinary morality, then a second dimension for empirical assessment concerns the direction of this divergence. One possibility is that legal ethics rules switch the "valence" of particular actions, that is, change whether an action is permitted or forbidden. ${ }^{10}$ For example, a legal ethics rule might permit or require a lawyer to act in a way that is morally prohibited. In such a case, the legal ethics provision would purport to "mint [a] moral permission[]." ${ }^{11}$ Divergence would also concern the permissibility of an action if a legal ethics rule prohibited a lawyer from acting in a way that was otherwise morally obligatory.

Even when legal ethics rules and ordinary morality assign the same valence to an action, they might still diverge in important ways. Legal ethics rules might be laxer than ordinary morality. For example, a legal ethics rule might make it optional for a lawyer to act in a way that is obligatory as a matter of ordinary morality. On the other hand, legal ethics rules might be stricter than ordinary morality ${ }^{12}$ Many actions are neither forbidden nor required by ordinary morality. Legal ethics rules might purport to change these "merely" permissible actions into requirements. If so, then legal ethics rules would subject lawyers to a higher standard than applies under ordinary morality by imposing a more demanding set of requirements. The lawyer's professional responsibilities would mainly forbid or require her to act in ways that are otherwise morally optional. ${ }^{13}$ If legal ethics rules diverge from ordinary morality, it is an open question whether this divergence concerns the permissibility of actions and, if not, whether legal ethics rules are laxer or stricter than ordinary morality.

A third dimension of assessment involves the patterns of divergence between legal ethics and ordinary morality. There are a variety of domains of legal ethics,

9. See, e.g., Bruce Green, The Role of Personal Values in Professional Decisionmaking, 11 Geo. J. LeGAL ETHICs 19, 22-23 (1997). ("[P]rofessional morality rarely will conflict with common moral norms, because so-called 'ethical' or 'moral' obligations are reflected in the rules of professional conduct just as other aspects of the 'law of lawyering' are strongly rooted in common morality.").

10. See Mark Lance \& Margaret Little, Where the Laws Are, in 2 Oxford Studies IN METAETHICs 149, 153-54, 163-64 (Russ Shafer-Landau ed., 2007) (explaining how changes in context can "switch[] the valences of certain morally significant features of acts").

11. Arthur Applbaum, Ethics for Adversaries: The Morality of Roles in Public and Professional LIFE 258 (2000).

12. See Sissela Bok, Can Lawyers Be Trusted?, 138 U. PA. L. Rev. 913, 922 (1990) (arguing that "codes of professional responsibility hold lawyers to stringent standards" with respect to general moral constraints on "deceit, violence, and breaches of promises, contracts, and laws").

13. For example, W. Bradley Wendel argues that the lawyer's discretion regarding client selection is and ought to be "circumscribed to a degree that would be intolerable in ordinary moral life." W. Bradley Wendel, Institutional and Individual Justification in Legal Ethics: The Problem of Client Selection, 34 HOFSTRA L. REV. 987, 991 (2005). 
reflecting different aspects of the lawyer's role. ${ }^{14}$ Perhaps, as some argue, patterns of divergence or convergence between legal ethics and ordinary morality generalize across these domains. For example, Geoffrey Hazard posits that legal ethics rules diverge from broader morality because the latter is categorical or universal, and thus fails to account for important values that apply to the context-sensitive ethical challenges that lawyers face. ${ }^{15}$ William Simon offers the converse assessment in support of the same conclusion: there is systematic divergence between legal ethics rules and moral judgments about justice because the former are categorical, while the latter are sensitive to context. ${ }^{16}$ Alternatively, Leo Katz argues that both legal ethics and ordinary morality have a formalistic structure. Many seemingly objectionable actions by lawyers simply capitalize on this formalism, and such capitalization is "perfectly defensibl[e]" under the standards of "everyday morality." 17 All three of these positions suggest patterns of divergence (in Hazard's and Simon's cases) or convergence (in Katz's case) are more or less the same across the various domains of legal ethics.

Others see divergence and convergence as domain-specific. On this position, legal ethics rules and ordinary morality converge in some domains, while diverging in others. For example, Susan Shapiro argues that legal ethics rules regarding conflicts of interest are stricter than generally applicable moral requirements. ${ }^{18}$ Likewise, W. Bradley Wendel contends that legal ethics rules about client selection and the formation of the attorney-client relationship are stricter than ordinary morality standards regarding affiliation. ${ }^{19}$ On the other hand, many commentators posit or imply that legal ethics provisions regarding

14. Below, we focus on five such domains: advocacy ethics (or the ethical strictures that apply to the lawyer's advancement of her client's position before a tribunal or against another party), counseling ethics (which apply to the lawyer's advising the client about what the law is and what the client should do), confidentiality ethics (which concern the lawyer's duty to maintain the client's secrets), the attorney-client relationship itself (which concerns the formation and termination of the attorney's representation of the client), and conflicts of interest (which concern both the content of the lawyer's duty of undivided loyalty and how to resolve challenges to this duty).

15. Geoffrey Hazard, Jr., Law Practice and the Limits of Moral Philosophy, in ETHICS IN PRACTICE 75-76 (Deborah Rhode ed., 2000).

16. Simon, supra note 6 , at $\$ 6$.

17. Leo Katz, Form and Substance in Law and Morality, 66 U. CHI. L. REv. 566, 566-67 (1999).

18. Susan Shapiro, Bushwhacking the Ethical High Road: Conflict of Interest in the Practice of Law and Real Life, LAW \& SOC. INQUIRY 87, 91 (2003) (concluding, based on empirical study of conflicts of interest across professions, that "lawyers . . . behave more ethically" than other professions "with respect to conflicts of interest").

19. See Wendel, supra note 13, at 991 ("'A]lthough the constitutive rules of the practice of lawyering permits the exercise of some limited amount of moral discretion in client selection (and in other aspects of the professional relationship), this discretion ought to be circumscribed to a degree that would be intolerable in ordinary moral life."); W. Bradley Wendel, Lawyers as Quasi-Public Actors, 45 ALTA. L. Rev. 83, 85 (2007) (distinguishing lawyers' professional responsibilities regarding client selection from those of "ordinary moral agents who can act as moral "filters" by refusing to represent certain categories of clients or refusing to take certain legally permissible actions on behalf of their clients"). 
advocacy ${ }^{20}$ and the maintenance of client confidences ${ }^{21}$ require lawyers to act in ways that would otherwise be morally impermissible.

Another position (logically possible, but not systematically articulated) is that legal ethics rules and ordinary moral judgments diverge and converge without any discernible pattern. Such haphazardness might be explained by the largely politicized process through which legal ethics rules are promulgated ${ }^{22}$ or the rent-seeking function that rules of professional conduct serve. ${ }^{23}$ If either of these explanations is correct, then the legal profession does not formulate legal ethics rules in order to bolster the moral justification for the lawyer's role and individual rules are not selected for their conformity with ordinary morality. As such, the thinking might go, convergence between legal ethics rules and ordinary moral judgments is a happy accident, a more or less random occurrence.

Thus, we can ask a series of interrelated empirical questions about the connections between legal ethics and ordinary morality. First, do legal ethics rules diverge from or converge with ordinary morality in classifying specific actions? Second, if there is divergence, what is the direction of this divergence? (Do legal ethics rules differ from ordinary morality concerning the permissibility of specific actions? If not, are legal ethics rules stricter or laxer than ordinary morality?) Third, are there patterns to divergence and convergence? We can combine the answers to these questions into four distinct hypotheses about the relationship between legal ethics and ordinary morality:

20. See, e.g., MARKoviTs, supra note 7, at 25 (contending that, in advocacy role, lawyers "come under professional obligations to do acts that, if done by ordinary people and in ordinary circumstances, would be straightforwardly immoral"); Robert Audi, The Ethics of Advocacy, 1 LEGAL THEORY 251, 274-75 (1995) (contending that ethically justifiable rules of criminal justice advocacy would prioritize lawyer's offering "negative defense" regarding adequacy of evidence, rather than "prevailing mode" which permits or requires offering "positive defenses" concerning innocence of client that lawyer knows to be guilty).

21. See Benjamin Freedman, A Meta-Ethics for Professional Morality, 89 ETHICs 1, 4-5 (1978) ("While confidentiality is a value in ordinary morality, it is a stronger value in professional morality, and in professional morality causes deviations from what we would ordinarily consider the morally correct decision. On the basis of professional morality, we may arrive at a practical conclusion not countenanced (in any straightforward way) by ordinary morality."); Deborah Rhode, Institutionalizing Ethics, 44 CASE W. RES. L. REV. 665, 675 (1994) (noting the "extent to which bar ethical rules [regarding confidentiality] have lost touch with ordinary moral intuitions").

22. See, e.g., Richard L. Abel, Why Does the ABA Promulgate Ethical Rules, 59 TEx. L. REv. 639, 668 (1980) (contending that rules of professional ethics serve the function of legitimating the legal profession, and as such constitute "an attempt by elite lawyers to convince themselves that they have resolved their ethical dilemmas"); Susan P. Shapiro, If It Ain't Broke.... An Empirical Perspective on Ethics 2000, Screening, and the Conflict-of-Interest Rules, U. ILL. L. Rev. 1299, 1301, (2003) (arguing that ABA's Ethics 2000 commission's proposed revisions for conflict of interest rules were a product of an unrepresentative sample of practitioners who "had a stake in the debate-axes to grind, constituents to serve; interests or ideologies to promote").

23. See Daniel R. Fischel, Lawyers and Confidentiality, 65 U. CHI. L. REv. 1, 3 (1998) (contending that legal ethics rules prohibiting the disclosure of confidential information "benefit[] lawyers because [they] increase[] the demand for legal services. The legal profession, not clients or society as a whole, is the primary beneficiary of confidentiality rules"). 
Global Divergence: Legal ethics rules systematically diverge from ordinary morality. Legal ethics rules purport either to permit lawyers to act in ways that are otherwise morally impermissible, or to exempt lawyers from generally applicable moral requirements or prohibitions. These patterns of divergence generalize across domains of legal ethics. ${ }^{24}$

Domain-Specific Divergence: Legal ethics rules diverge from ordinary morality in some domains of legal ethics. In other domains, legal ethics provisions either converge with ordinary morality or impose stricter ethical standards on lawyers than those applicable in ordinary morality. ${ }^{25}$

Unpatterned Divergence: Legal ethics diverge from ordinary morality, but this divergence varies both within and across domains of legal ethics.

Global Convergence: Legal ethics rules either systematically converge with ordinary morality, or else impose stricter ethical requirements on lawyers than apply in ordinary morality. This pattern is realized across all domains of legal ethics. $^{26}$

Whether any of these hypotheses is true is an open empirical question. Yet the answer to this question matters a great deal. For example, consider theoretical debates about whether the lawyer's professional actions are morally justified. Many of these debates concern a version of Charles Fried's question about

24. Those who advance this hypothesis include Geoffrey C. Hazard Jr., My Station as a Lawyer, 6 GA. ST. U. L. REv. 1, 16 (1989) (arguing that legal ethics rules requiring a lawyer to "represent a client zealously, within bounds only of the law, regardless of the consequences to the other party" is "amoral and, indeed, immoral in terms of the universal moral code"); SiMON, supra note 6, at 138-69 (articulating and defending a "contextual view" about justification for lawyer's professional actions, which conflicts with categorical framing that underlies current legal ethics rules); Gerald Postema, Self-Image, Integrity, and Professional Responsibility, in THE GOOD LAWYER 286, 288-89 (David Luban ed., 1983) (proposing that lawyer's professional requirements would be subject to moral censure if performed outside of professional role).

25. Predictions of domain-specific divergence include Bernard Williams, Professional Morality and its Dispositions, in THE GOOD LAWYER 259, 268 (David Luban ed., 1983) (arguing that professional moralities likely to emphasize some virtues more than rest of society, while deemphasizing others); DAvID LUBAN, LAWYERS AND JUSTICE: AN ETHICAL STUDY 148-74 (1986) [hereinafter LUBAN, LAWYERS AND JUSTICE] (contending that, in civil contexts, legal ethics rules regarding "limited zeal" are justified, while rules regarding client's control over moral considerations and lawyer's control over tactics are unjustified); David Wilkins, Legal Realism for Lawyers, 104 HARV. L. REV. 468, 514-15 (1990) (arguing for inevitability of situations "in which the rules of professional conduct ... prohibit lawyers from acting ways that, from the position of the actor, are legally or morally justified").

26. Among those who predict global convergence are Fried, supra note 2, at 1065-66; Katz, supra note 17, at 566-67 ("Everyday morality is highly formalistic, in a sense not usually appreciated. Law tracks everyday morality, and is thus also formalistic in that same unappreciated sense. Lawyers who engage in the [tactics that exploit loopholes to advance client's interests] are simply capitalizing on the formality of the everyday morality that underlies law. And by the standards of that same everyday morality they are acting perfectly defensibly."); Ted Schneyer, Some Sympathy for the Hired Gun, 41 J. LeGAL EDUC. 11, 13 (1991) ("II]f there is a problem with the content of legal ethics, it might well be that the field corresponds too closely with ordinary morality, not that the discrepancies are too great."); M. B. E. Smith, Should Lawyers Listen to Philosophers About Legal Ethics?, 9 LAW \& PHIL. 67, 83 (1990) (conjecturing that "a moral layperson would agree that the moral weight of lawyers' role obligations is quite substantial," which implies that lawyer's zealous advocacy on behalf of her client would amount to following "both common moral opinion and [her] own moral inclination"). 
whether a "good lawyer [can] be a good person."27 If the global divergence hypothesis were true, then it might be difficult to answer Fried's question in the affirmative. Being a good lawyer would routinely involve acting in morally impermissible ways, which is (arguably) incompatible with being a "good" person. $^{28}$

Alternatively, the truth of global divergence might not require a negative answer to Fried's question. A good person could do the morally objectionable things required to be a good lawyer, so long as the legal system itself were morally justified. ${ }^{29}$ Yet, one can also use the truth of global divergence to argue that Fried's question is inapt: because it is impossible to provide a direct moral justification for the professional actions of lawyers, we should not ask whether good lawyers can be good people so much as whether the professional actions of lawyers are politically justified. ${ }^{30}$ Conversely, if global convergence were true, then acting in the ways that a good lawyer acts would not compromise one's status as a morally good person. Fried's question would yield an unambiguously positive answer.

Divergence is also an important issue in policy debates about what laws and rules should govern the professional conduct of lawyers. Some commentators take the empirical divergence of certain legal ethics rules from ordinary morality to support the normative conclusion that these divergent rules should be reformed. ${ }^{31}$ Others contend that, because legal ethics rules do not diverge from ordinary morality in the first place, there is no urgent need to reform these rules. ${ }^{32}$ Both of these arguments adopt a common premise, namely that the fact of a rule's divergence from ordinary morality would provide prima facie reason to change the rule.

In sum, whether (and, if so, how) legal ethics rules diverge from ordinary morality is an open empirical question, one that has crucial implications for contemporary theoretical and policy debates about the legal profession.

27. See Fried, supra note 2, at 1060.

28. See Gerald J. Postema, Moral Responsibility in Professional Ethics, 55 N.Y.U. L. Rev. 63,64 (1980) (arguing that, on prevailing conception of lawyer's role, it is "not possible" to "achieve a fully integrated moral personality").

29. See DARE, supra note 7 , at $\$ 4$ (arguing that justification for lawyer's partisanship on behalf of client, regardless of moral status of client's actions, derives from function of law and function of lawyer's role within legal institutions).

30. See MARKovITS, supra note 7, at 166 (arguing that lawyer's professional actions, while ordinarily immoral, are justified in terms of their contribution to process that legitimately resolves political conflicts).

31. See RHODE, IN THE INTERESTS OF JUSTICE, supra note 6 , at $\$ 4$ (arguing for reform of rules regarding confidentiality and advocacy on grounds that these "overvalue[] lawyers' and clients' interests at the expense of the public's").

32. See, e.g., Stephen L. Pepper, Why Confidentiality, 23 Law \& Soc. INQuiRY 331, 335-36 (1998) (opposing calls for substantial reform to legal ethics rules regarding client confidentiality, on grounds that confidentiality "means that the lawyer, in essence, promises not to reveal or otherwise do anything harmful to the client as a result of learning" potentially damaging facts about the client). 


\section{B. HOW MUCH DOES THE LAWYER'S ROLE MATTER MORALLY?}

Lawyers confront important ethical questions concerning the limits of justifiable partiality, the demands of confidentiality, and the resolution of conflicts of interest. Other professions face similar (if not identical) challenges. Yet many lawyers and legal ethicists contend that novel principles do and should apply to the ethical worlds of lawyers. For example, some defend the principle of partisanship, or the view that "[w]ithin, but all the way up to, the limits of the law, the lawyer must be committed to the aggressive and single-minded pursuit of the client's objectives," even if doing so conflicts with the interests of others. ${ }^{33}$ Physicians, too, are often charged with advocating on behalf of their patients. Yet few medical ethicists would contend that anything like the principle of partisanship should apply to the professional actions of physicians. Likewise, both lawyers and physicians are charged with keeping client confidences. Few argue that physicians should be required (or allowed) to maintain some confidences when doing so would result in serious harm to others. On the other hand, many legal ethicists contend that lawyers should be required to keep client confidences in exactly these circumstances. What might explain or justify this difference between the ethical responsibilities of lawyers and those of other professionals? One possible explanation of and justification for this difference is based on features that are distinctive to the lawyer's professional role. There are two possible claims here, one weaker and one stronger. We call the weaker claim the lawyer distinctiveness thesis (LDT): role-based considerations partially determine the status of the lawyer's action.

The proponent of LDT posits that generally applicable normative considerations underdetermine what a lawyer is permitted or required to do. Rather, factors specific to the lawyer's role (like the rules of professional conduct and values associated with the legal profession) are necessarily relevant to establishing whether a lawyer should be permitted or required to act in a particular way. The distinctiveness of the lawyer's role is close to an article of faith among the legal profession. In his famous lectures to incoming law students, for example, Karl Llewellyn illustrates this point by evoking Rabelais:

[T] he [legal] profession is charged with being what any profession should hope to be: expert enough to develop a sort of black art of its own. All that makes law grotesque and dubious is that any man thinks he has adequate knowledge by his common sense to judge of "rights" and "wrongs." What lawyers do must therefore be the diabolical cozenages of Cepola. ${ }^{34}$

33. DARE, supra note 7, at 5 .

34. Karl N Llewellyn, The Bramble Bush: The Classic lectures on the Law and Law School 160 (2008). 
Something like Llewellyn's dictum is foundational in many theoretical arguments about legal ethics. These arguments take for granted that the lawyer's role has distinctive significance and focus instead on questions of when, why, and how much significance is endowed in this role. ${ }^{35}$ However, some scholars implicitly deny LDT by positing that general moral considerations are both necessary and sufficient to establish the status of the lawyer's professional actions. ${ }^{36}$ A stronger claim is that the lawyer's role is exceptional, generating permissions and requirements that differ from all other professions. On what we call the lawyer exceptionalism thesis (LET): the standards for determining the status of the lawyer's action differ from those applicable to other professional roles in analogous circumstances.

LET entails that the lawyer's role has a unique capacity to (in Arthur Applbaum's phrase) "mint" moral permissions, that is, to make it the case that a lawyer is permitted (or required) to act in ways that are forbidden for other professional roles. If valid, LET would justify the prerogatives to depart from generally applicable moral requirements that many lawyers claim to have. LET would also justify why the rules of legal ethics differ from those governing other professions in analogous circumstances.

Courts, ${ }^{37}$ lawyers, ${ }^{38}$ and legal ethicists ${ }^{39}$ defend lawyer exceptionalism based

35. See, e.g., Alan H. Goldman, The Moral Foundations of Professional Ethics 2-33 (1980) (arguing that many professional ethics codes treat professional duties as capable of outweighing ordinary moral considerations, elevating some goals or values to paramount importance, such that the central problem of professional ethics is whether professionals ought to adhere to these "strongly differentiated" official codes).

36. See Alan Strudler, Belief and Betrayal: Confidentiality in Criminal Defense Practice, 69 U. CIN. L. REv. 245,248 (2000) (arguing that a lawyer's obligations to client arise out of "deontological moral basis" of client's rights, rather than considerations specific to lawyer's role).

37. See, e.g., Updike, Kelly \& Spellacy, P.C. v. Beckett, 850 A.2d 145, 169 n.28 (Conn. 2004) (stating that the attorney-client relationship "imposes a fiduciary duty on the attorney . . . characterized by a unique degree of trust and confidence between the parties, one of whom has superior knowledge, skill or expertise and is under a duty to represent the interests of the other") (internal quotation marks omitted); In re Cooperman, 83 N.Y.2d 465,472 (N.Y. 1994) ("The duty to deal fairly, honestly and with undivided loyalty superimposes onto the attorney-client relationship a set of special and unique duties, including maintaining confidentiality, avoiding conflicts of interest, operating competently, safeguarding client property and honoring the clients' interests over the lawyer's."); Florida Bar v. Ward, 599 So. 2d 650, 652 (Fla. 1992) (noting the "unique fiduciary duty which lawyers, individually and as a profession, owe to their clients"); Cardenas v. Ramsey Cnty., 322 N.W.2d 191, 193 (Minn. 1982) (noting the "obligations imposed . . . by the unique fiduciary relationship existing between attorney and client").

38. See Sung Hui Kim, Lawyer Exceptionalism in the Gatekeeping Wars, 63 S.M.U. L. REv. 73, 86 (2010) (citing ABA Section of Corp., Banking, \& Bus. Law, SEC Standard Conduct for Lawyer: Comments on the SEC Rule Proposal (Release No. 33-6344), 37 Bus. LAW 915, 916 (1982) (positing "the importance to society of lawyers' unique professional obligations" in arguing against proposed SEC regulations requiring revelation of client fraud)).

39. See, e.g., William Sage, Physicians as Advocates, 35 Hous. L. REv. 1529, 1607 (1999) ("As a general matter, lawyers' obligations to society are more closely circumscribed than physicians', which is a direct result of the former profession's overarching role as advocate."); APPLBAUM, supra note 11, at 200 ("[L]awyers in [adversary equipoise] are sufficiently different from those adversaries in equipoise that take up space in the popular imagination ... that no inference about politics and government can be drawn."); W. Bradley Wendel, The Deep Structure of Conflicts of Interest, 16 GEO. J. LeGAL ETHICs 473, 503 (2003) ("[L]awyers, to a greater 
on the unique social functions of the lawyer's role. Other commentators accept that the lawyer's role bears distinctively on the status of actions, but deny that it can generate exceptional prerogatives or requirements. ${ }^{40}$ LET is also a central component of many real-world discussions of the legal profession. Imparting the logic of exceptionalism is an integral part of the professional socialization of lawyers. ${ }^{41}$ LET is also routinely invoked in debates about the rules that should govern lawyers. ${ }^{42}$

Both distinctiveness and exceptionalism are (at least in part) normative claims. As such, neither can be directly falsified by empirical examination, as can the

extent than most [other] occupational groups . . . owe an obligation of loyalty to a client whose interests may not be congruent with the public good."); Fred C. Zacharias, Integrity Ethics, 22 GEo. J. LeGAL ETHICs 541, 553 (2009) ("Ethics codes incorporate rules of role to identify lawyers' unique perspective, help lawyers understand what their special situation requires, provide incentives (including potential discipline) to motivate lawyers to honor the demands of the legal system and, to some extent, enable lawyers to justify their special conduct to clients and the outside world."); W. Bradley Wendel, Razian Authority and Its Implications for Legal Ethics, 13 LEGAL ETHICS 191 (2010) ("To the extent that the lawyer's role has any normative significance, however, its significance is bound up with the law's function of settling moral and empirical conflict."); Ronald D. Rotunda, Why Lawyers are Different and Why We are the Same: Creating Structural Incentives in Large Law Firms to Promote Ethical Behavior - In-House Ethics Counsel, Bill Padding, and In-House Ethics Training, 44 AKRON L. REv. 679, 724 (2011) ("Our ethics rules make lawyers different than other professionals ...."); W. Bradley Wendel, Three Concepts of Roles, 48 SAN DiEgo L. REv. 547, 574 (2011) ("There is something distinctive about the law, legal reasoning, and the role of lawyers.").

40. See, e.g., Fried, supra note 2, at 1073 ("[T] he need which the lawyer serves in his special-purpose friendship may not be, as in the case of the doctor, natural, pre-social. Yet it is a need which has a moral grounding analogous to the need which the physician serves: the need to maintain one's integrity as a person."); Thomas L Shaffer, The Unique, Novel, and Unsound Adversary Ethic, 41 VAND. L. REv. 697, 699 (1988) (contending that the "adversary ethic" which characterizes lawyer's professional responsibilities in America "is a unique professional notion"); Geoffrey C. Hazard, Jr., Dimensions of Ethical Responsibility: Relevant Others, 54 U. PITT. L. REv. 965, 966 (1992) ("[E]ssentially the same basic dimensions of ethical responsibility may be used to analyze ethics in the practice of law as may be used to analyze ethics in other vocational situations and in everyday life ... . [because] these dimensions are inherent in all ethical problems."); LUBAN, LEGAL ETHICS AND Human DignITY, supra note 6 , at $\$ 2$ (arguing that justification for lawyer's role derives from generally applicable concern for protection and promotion of human dignity); Ronald Rodes, Jr, Forming an Agenda-Ethics and Legal Ethics, 77 Notre DAME L. Rev. 977, 978-79 (2001) ("While the moral problems we encounter in our profession are often unique, the moral standards and intuitions we must use in solving them are not."); Thomas Morawetz, Confidentiality and Common Sense: Insights from Philosophy, 48 SAN DiEGo L. REv. 357, 372-73 (2011) ("No protocols like the rules of lawyer confidentiality exist to tell doctors when to disregard the welfare of patients who are not the doctor's or to tell the employer when it may harm nonemployees with impunity .... [W] [Wen partiality is recognized in our moral intuitions, it never yields a moral carte blanche to disregard the interests of others."); Benjamin Zipursky, Legal Positivism and the Good Lawyer: A Commentary on W. Bradley Wendel's Lawyers and Fidelity to Law, 24 Geo. J. LeGaL ETHICs 1165, 1175 (2011) (contending that lawyer's duty to client, like physician's duty to patient, is connected to aspects of well-being in which lawyer has professional expertise).

41. See, e.g., Elizabeth Mertz, The Language of Law School 28, 121 (2007) (describing "linguistic ideology and metapragmatic structuring" implicit in law school pedagogy which encourages law students to remove "emotion and morality (as it is commonly understood) in dealing with human conflict and the people who appear in legal conflict stories").

42. For example, Sung Hui Kim describes the organized bar's appeal to lawyer exceptionalism as a way of resisting SEC regulation and "gatekeeping" responsibilities dating as far back as the 1970s. See Kim, supra note 38 , at $78-83$. 
hypotheses about divergence described above. Nonetheless, each of these views can be evaluated empirically for its "descriptive adequacy," or its capacity to account for people's considered judgments (if any) about the normative significance of professional roles and the operative principles (if any) by which people reach these judgments. ${ }^{43}$ Either thesis would be descriptively inadequate if it did not accord with lay judgments about the significance of the lawyer's role. That is, LDT would be descriptively inadequate if empirical moral judgments did not assign a distinctive significance to the lawyer's professional role, and LET would be descriptively inadequate if these judgments did not attribute unique moral status to the professional actions of lawyers. Descriptive inadequacy would be a good reason to reject either thesis, regardless of its theoretical appeal. ${ }^{44}$

We can test the descriptive adequacy of LDT and LET in the same ways that we verify other empirical hypotheses about legal ethics. This process involves identifying cases where (all else equal) variations in the description of someone's professional role (i.e., attorney vs. non-attorney) are associated with differences in judgments about the status of specific actions. In other words, moral judgments about a lawyer's acting in a certain way should differ significantly from judgments about a non-lawyer performing the same action. If this effect were not realized, then there would be reason to doubt a central claim of both LDT and LET- that the lawyer's role (as such) matters to the status of the lawyer's action. LET makes a further prediction: that the lawyer's role can "switch" the valence of a particular action from permitted to forbidden (or vice versa). In other words, LET posits that there are at least some cases where a lawyer will be permitted or required to act in ways that (all else equal) are impermissible for non-lawyers. If empirical moral judgments do not exhibit such a "switching" effect, then there would be reason to doubt a central claim of lawyer exceptionalism-namely, that the lawyer's role has the unique capacity to mint moral permissions.

\section{DO PROFESSIONAL NORMS DETERMINE THE LAWYER'S REASONS?}

Many debates in legal ethics concern the rules of legal ethics as a source of the reasons that a lawyer has. According to one family of views, what a lawyer has most reason to do depends on the prescriptions of generally applicable normative principles. ${ }^{45}$ On another family of views, what a lawyer has most reason to do

43. See MikHall, supra note 4 , at $\$ 2.1 .6$.

44. For more on why descriptive inadequacy is a basis for assessing substantive theories about legal ethics, see Stephen Galoob, How Do Roles Generate Reasons? A Method of Legal Ethics, 15 LeGAl ETHICs 1, 9-10 (2012). In short, a substantive theory of legal ethics is an attempt to describe the normative significance of a lawyer's role. If a theory is descriptively inadequate, then we can question whether it describes the significance that the lawyer's role actually has, rather than the significance that it might have.

45. See, e.g., SImon, supra note 6 , at $\S 6$ (arguing that lawyer's professional actions are justified to the extent that they promote justice understood as "legal merit"); Strudler, supra note 36, at 248 (contending that lawyer's professional responsibilities should accord with the "logical structure" of moral autonomy). 
depends on of the values served by the legal profession and the legal system more broadly. ${ }^{46}$ On either of these positions, locally applicable rules and norms of professional conduct do not fully determine the reasons that a lawyer has. Rather, these rules and norms matter derivatively insofar as they serve broader moral or professional values. Legal ethics rules and norms do not provide conclusive reasons for lawyers to act when they conflict with (rather than facilitate) these moral or professional values.

Still another family of views advances what we will call the professional norms thesis (PNT): so long as the legal system is legitimate, the professional norms governing the conduct of lawyers in a jurisdiction determine what a lawyer has most reason to do. ${ }^{47}$

PNT denies that the lawyer's reasons for action are best explained by broader moral or professional values. The advocate of PNT might allow that moral or professional values provide decisive reason for the lawyer to act in cases where there is no applicable professional norm. However, when a professional norm applies to a case, that norm is decisive. PNT provides a definitive resolution of the practical question about what a lawyer should do in a particular case: the lawyer should abide by professional norms, even when doing so conflicts with broader moral or professional values.

By way of illustration, suppose that the applicable rules governing lawyers deem it obligatory for the lawyer to maintain certain client confidences. According to PNT, these rules would provide conclusive reason for a lawyer to

46. See, e.g., Monroe H. Freedman, In Praise of Overzealous Representation-Lying to Judges, Deceiving Third Parties, and Other Ethical Conduct, 34 HofsTRA L. REv. 771, 782 (2005) (contending that professional values served by lawyer's zealous representation "may sometimes require the lawyer to violate ... salutary disciplinary rules"); Fred Zacharias \& Bruce Green, Reconceptualizing Advocacy Ethics, 74 GEO. WASH. L. REv. 1, 45 (2005) (articulating the notion of "professional conscience," exercise of which requires lawyer to "attempt to strike a fair balance between competing professional values and interests" in deciding what to do).

47. There are stronger and weaker versions of PNT, which differ based on the defeasibility of professional norms by broader moral or professional values. Those who take the weaker position include LUBAN, LEGAL ETHICS AND HUMAN DigniTY, supra note 6, at 13 (arguing that professional obligations provide defeasible moral baselines which have presumptive weight when in conflict with ordinary morality) and Postema, supra note 28, at 82-83 (advocating a "recourse role" conception of lawyer's role, under which a lawyer's professional "duties and responsibilities" may expand or contract depending on the institutional objectives the role is designed to serve). Advocates of the latter, stronger position include MiChaEL. DAVIS, PROFESSION, CODE AND ETHICS 25-28 (2002) (arguing that professional codes have moral authority over members of profession); W. Bradley Wendel, Civil Obedience, 104 ColuM. L. REv. 363, 395 (2004) (advocating conception of lawyer's role under which professional obligations preempt first-order moral reasons and exclude them from consideration in lawyer's deliberation); W. Bradley Wendel, Legal Ethics and the Separation of Law and Morals, 91 CoRNELL L. REv. 67, $72-73$ (2005) (articulating the view that law governing lawyers "excludes recourse to first-order moral considerations in [the lawyer's] practical reasoning"); W. Bradley Wendel, Moral Judgment and Professional Legitimation, 51 ST. Lous U. L.J 1074 (2006) ("[E]ven if they have analogues in ordinary moral life . . . Legal policy/moral concepts and values take on a specific meaning in legal contexts, which is all that lawyers are professionally concerned with. Of course, lawyers remain moral agents even when acting in a professional capacity, but their non-legal moral beliefs should not be permitted to influence their interpretation and application of legal norms."). For the sake of clarity, our discussion of PNT focuses on the latter, stronger version. 
maintain client confidences, regardless of whether doing so would be morally justifiable or serve central professional values. Moreover, if the applicable rules forbade the lawyer from maintaining such client confidences, then the lawyer would have decisive reason not to maintain them. Thus, PNT posits that the professional norms applicable to lawyers can, by themselves, change the deontic status of a lawyer's actions. To deny PNT is to deny that professional norms can effect such changes. ${ }^{48}$

PNT is a normative argument. As such, it is not directly falsifiable. However, as with the theses about distinctiveness and exceptionalism described in Part I(b), we can examine whether PNT is descriptively adequate. PNT makes at least two empirically verifiable predictions. First, PNT predicts that professional norms influence judgments about the status of the lawyer's action. In other words, introducing a professional norm concerning a lawyer's action in a particular case will be associated with a significant difference in judgments about the case, over and above the moral and professional values implicated in the case. If this effect were not realized, then the relevant moral or professional values would be sufficient to ground the judgment, and (contra PNT) the professional norm could be otiose.

Second, PNT predicts that professional norms can (at least sometimes) "switch" the valence of certain action-in other words, that there are cases where an action is forbidden in the absence of a professional norm but permitted (when licensed) or obligatory (when required) by a professional norm. If PNT is descriptively accurate, then professional norms must always influence ordinary moral judgments and must (at least sometimes) switch judgments about the status of actions. ${ }^{49}$ If not, then we can doubt that PNT accurately describes the operative principles of our normative world.

$* * *$

To summarize this Part, the empirical questions which underlie divergence, distinctiveness, and professional norms are central to theoretical debates about legal ethics. Different theories of legal ethics presuppose or support different

48. See, e.g., APPlBauM, supra note 11 , at 259 (contending that professional roles cannot generate permission to act in way that is otherwise forbidden); Bok, supra note 12, at 923 ("[L]awyers, like others, may encounter exceptional crises in which a lie offers the only alternative to save, say, an innocent life, and in which they are certain that they will be able to justify their choice publicly once the crisis is over. But there is nothing about being a lawyer which adds legitimacy to such choices."); Alan Gewirth, Professional Ethics: The Separatist Thesis, 96 ETHICS 282, 300 (1986) ("[P]rofessional ethics falls under the same general principle of morality as do all other branches of ethics.... While professionals may engage in activities that are proximately justified by the specific ends or purposes of their profession, and that are not permitted to persons who lack the relevant expertise and other qualifications, those activities may not transgress the requirements that are set by the general principle of morality."); Richard Wasserstrom, Roles and Morality, in THE GOOD LAWYER 25, 35-36 (David Luban ed., 1983) (arguing that relevant questions about justification and significance of role requirements are matters of morality simpliciter).

49. An alternative view to PNT might concede that professional norms have distinctive significance, but reject the claim that professional norms can "switch" the permissibility of an action. 
answers to each of these questions. In the next two Parts we provide a measure for testing these questions, as a way of illuminating these theoretical debates.

\section{DATA AND METHODOLOGY}

We used a survey experiment to collect data that addresses the empirical theses and hypotheses described in Part I. This research method is common in moral psychology and experimental philosophy. ${ }^{50}$ We applied one-sample and twosample $t$-tests in data analysis to test these empirical claims.

\section{A. PARTICIPANTS}

122 people participated in the study ( 59 percent female, mean age $=21.5$ ). Participants were recruited from the subject pool of the Experimental Psychology Laboratory at U.C. Berkeley's Haas School of Business. The majority of participants were U.C. Berkeley undergraduates. Participants were paid $\$ 10$ for successfully completing the survey.

50. See generally Bryce Huebner, Critiquing Empirical Moral Psychology, 41 PHIL. Soc. Scl. 50, 54 (2011) (describing "structure of the typical experiment" in "empirical moral psychology" as utilizing "standard survey methods used in social psychology: experimenters ask participants to read about some weird things before asking them to convert their thoughts into a number along a specified continuum"). Recent examples of using the vignette survey experiments to examine the content or drivers of moral judgments include Fiery Cushman \& Liane Young, Patterns of Moral Judgment Derive From Nonmoral Psychological Representations, 35 CoGNITTVE SCI. 1075 (2011) (using survey experiment to examine how nonmoral psychological representations mediate act/omission and means/side-effect judgments); Fiery Cushman, Joshua Knobe \& Walter SinnottArmstrong, Moral Appraisals Affect Doing/Allowing Judgments, 108 CoGNITION 281 (2008) (using survey experiment to examine how moral appraisals shape doing/allowing judgments); Fiery Cushman, Liane Young \& Marc Hauser, The Role of Conscious Reasoning and Intuition in Moral Judgment: Testing Three Principles of Harm, 17 PsychOL. SCI. 1082 (2006) (using survey experiment to identify principles utilized by subjects in judgments about moral dilemmas); Joshua Greene et al., Pushing Moral Buttons: The Interaction Between Personal Force and Intention in Moral Judgment, 111 Cognrtion 364 (2009) (using survey experiment to gauge influence of "personal force" assessments on moral judgments and intentional attributions); Tania Lombrozo, The Role of Moral Commitments in Moral Judgment, 33 CoGNITIVE SCI. 273 (2009) (using survey experiment to examine how moral commitments mediate judgments regarding moral dilemmas); MIKHAIL, supra note 4, at $\$ 4$ (reporting results of survey experiment on judgments in "trolley problem" cases to derive "operative principles" of moral judgment); Shaun Nichols \& Joshua Knobe, Moral Responsibility And Determinism: The Cognitive Science Of Folk Intuitions, 41 Nous 663 (2007) (using survey experiment to support view that lay judgments about moral responsibility differ based on formulation of scenario in abstract or concrete terms); Shaun Nichols \& Ron Mallon, Moral Dilemmas And Moral Rules, 100 COGNITION 530 (2006) (utilizing survey experiment to contend that "a complex set of psychological processes, including representations of rules, emotional responses, and assessments of costs and benefits" drive lay judgments about permissibility of actions). This survey experiment method, although relatively standard, is not without its critics. See J.F. Christensen \& A. Gomila, Moral Dilemmas in Cognitive Neuroscience of Moral Decision-making: A Principled Review, 36 NEUROSCI, \& BIOBEHAVIORAL REv. 1249, 1251-52 (2012) (contending that heterogeneity in studies of moral judgment through responses to moral dilemmas prevents comparison and replication of findings across studies); Simon Cullen, Survey-Driven Romanticism, REv. PHIL. \& PsYcHOL. (2010) (arguing that methodological errors in experimental philosophy studies confound the inference that participants' survey responses reflect folk intuitions). 


\section{B. EXPERIMENTAL PROCEDURES}

Participants completed a web-based survey containing 16 items (15 test, 1 control). Each tested item contained a scenario involving professional ethics. Participants rated the protagonist's action or omission on a scale from 1 to 7 , anchored at 1, 4, and 7 (where 1="Forbidden," $4=$ "Permitted," and $7=$ "Obligatory"). Scenarios were presented one at a time, with the order randomized among participants.

We used a $2 \times 2$ between-subjects design, with participants randomly assigned to one of four conditions. For each scenario, we manipulated the affective description of the scenario (high affect vs. low affect) and either the role of the protagonist (attorney vs. non-attorney) or the existence of a non-controlling professional norm (extant professional norm vs. silence about existence of professional norm). Participants received one version of each scenario.

We analyzed data only from participants who successfully completed all 16 items. Participants were omitted from all analyses if they either failed the control scenario or completed any of the scenarios in fewer than $6 \mathrm{~s}$, which we deemed the minimum comprehension and response time on the basis of pilot research. After dropping the data, the responses of 107 participants remained for analysis.

\section{MATERIALS}

General instructions introduced the task to participants. ${ }^{51}$ The key part of these instructions read as follows (emphasis in original):

You will read about several situations involving professional ethics. For each test item, you will be presented with a scenario followed by a question. We are interested in knowing your moral or ethical judgments about these questions, not what you think the rules of professional ethics actually say.

All items on the instrument concerned ethical questions that arise in professional roles. Most of the items were derived from sample questions on the Multistate Professional Responsibility Examination (MPRE), a multiple-choice examination administered on behalf of the National Conference of Bar Examiners. The MPRE tests knowledge of the law governing the conduct of lawyers, including the American Bar Association's (ABA) Model Rules of Professional Conduct and "generally accepted principles established in leading federal and state cases and in procedural and evidentiary rules." ${ }^{2}$ Other items were adapted from secondary resources on legal ethics.

We developed the items using the following method. First, we identified five domains of legal ethics that are typically thought to implicate moral consider-

51. See Supporting Information File, GEORGETOWN JOURNAL of LEGAL ETHICS website.

52. See Multistate Professional Responsibility Examination Information Booklet 3 (2011). 
TARLE 1: LIST OF SURVEY ITEMS BY DOMAIN

\begin{tabular}{|c|c|}
\hline Domain & Topic \\
\hline Advocacy ethics & $\begin{array}{l}\text { Lawyer's duty to advance client's interests by taking advantage of } \\
\text { misfortune of adversary (HARD) } \\
\text { Lawyer's duty to brutally cross-examine a truthful rape witness in order to } \\
\text { undermine her credibility (CROSS-EX) } \\
\text { Lawyer's duty to reveal information about client's criminal history in order } \\
\text { to correct court's mistake that, if uncorrected, would result in lenient } \\
\text { sentence for client (CANDOR) } \\
\text { Lawyer's duty to introduce alibi testimony that the lawyer suspects, but } \\
\text { does not know for certain, to be perjured (DOUBTFUL) }\end{array}$ \\
\hline Counseling ethics & $\begin{array}{l}\text { Lawyer's duty to provide honest advice that might be used by client to } \\
\text { violate legal standards. } 53 \text { (CAE) } \\
\text { Lawyer's duty to provide honest advice that might result in harms to } \\
\text { identifiable third-parties (PATCOUN) }\end{array}$ \\
\hline Attorney-client relationship & $\begin{array}{l}\text { Lawyer's prerogative to decline representation of client based on moral } \\
\text { disapproval of client or client's case (SELECT) } \\
\text { Lawyer's prerogative to "turn a present client into a former client by "firing' } \\
\text { the client in order to get the benefit of the more lenient conflict of interest } \\
\text { rules that apply to former clients" } 54 \text { (POTATO) }\end{array}$ \\
\hline Confidentiality & $\begin{array}{l}\text { Lawyer's duty to maintain client confidences in light of risk of substantial, } \\
\text { imminent harm to others } 55 \text { (SPAULD) } \\
\text { Lawyer's duty to maintain client confidences in light of risk of substantial, } \\
\text { past harm to others } 56 \text { (PLEASANT) } \\
\text { Lawyer's duty to maintain client confidences related to client's prior perjury } \\
\text { (PERJURY) } \\
\text { Lawyer's duty to maintain client confidences concerning past fraudulent } \\
\text { activity that implicated the lawyer's services (FRAUD1) } \\
\text { Lawyer's duty to maintain client confidences concerning future fraudulent } \\
\text { activity that implicates the lawyer's service (FRAUD2) }\end{array}$ \\
\hline Conflicts of interest & $\begin{array}{l}\text { Lawyer's prerogative to avoid concurrent conflict of interest through use of } \\
\text { non-consensual ethical screen (SCREEN) } \\
\text { Lawyer's duty of loyalty in light of acquired conflicts of interest between } \\
\text { clients (or between client and third-party payer) (AQCOI) }\end{array}$ \\
\hline
\end{tabular}

ations: advocacy, counseling, confidentiality, attorney-client relationship, and conflicts of interest. Within each domain, we identified topics that have been the subject of extensive discussion by legal ethicists and the Bar. We selected topics that (a) have attracted considerable scholarly debate; (b) are widely thought to raise dilemmas between professional responsibilities and paradigmatic moral

53. See Stephen L. Pepper, Counseling at the Limits of the Law: An Exercise in the Jurisprudence and Ethics of Lawyering, 104 YALE L.J. 1545, 1548 (1995).

54. John Leubsdorf, Conflicts of Interest: Slicing the Hot Potato Doctrine, 48 SAN Diego L. Rev. 251, 252 (2011).

55. This scenario is adapted from Spaulding, 116 N.W.2d at 710 .

56. This scenario was based on the so-called Lake Pleasant "hidden bodies" case. People v. Beige, 372 N.Y.S.2d 798 (1975), affd., 376 N.Y.S.2d 771 (1976) , aff'd., 359 N.E.2d 377 (N.Y. 1976). 
Table 2a: Example of Experimental Design in Attorney/Non-AtTorney Items

\begin{tabular}{|c|c|}
\hline PERJURY: Attorney Versions & PERJURY: Non-attorney Versions \\
\hline $\begin{array}{l}\text { Larry Lawyer has been hired to defend Burt } \\
\text { Businessman against a criminal charge of } \\
\text { embezzlement. (Burt had previously been charged } \\
\text { with embezzlement several years ago, while } \\
\text { working for a different company. He was found } \\
\text { "not guilty" of those charges.) In preparation for } \\
\text { the trial, Burt tells Larry the following: } \\
\text { "You wouldn't believe the kind of lies I told in that } \\
\text { other case. But it was worth it; I [Low Affect } \\
\text { Version: didn't do anything in the first place, } \\
\text { although I wish I had!; High Affect Version: } \\
\text { blamed the whole thing on my jerk boss, and he's } \\
\text { rotting in jail even though he didn't do anything!] } \\
\text { But, obviously, keep this to yourself." } \\
\text { For Larry Lawyer, telling the authorities about Burt's } \\
\text { false testimony in the prior case is: }\end{array}$ & $\begin{array}{l}\text { Burt Businessman is a client of Steve } \\
\text { Social, who is a licensed clinical social } \\
\text { worker. A few years ago, Burt was } \\
\text { charged with embezzling from his } \\
\text { company, but found "not guilty." In a } \\
\text { counseling session with Steve, he says } \\
\text { the following: } \\
\text { "You wouldn't believe the kind of lies I } \\
\text { told in that case. But it was worth it; I } \\
\text { [Low Affect Version: didn't do } \\
\text { anything in the first place, although I } \\
\text { wish I had!; High Affect Version: } \\
\text { blamed the whole thing on my jerk boss, } \\
\text { and he's rotting in jail even though he } \\
\text { didn't do anything!] But, obviously, } \\
\text { keep this to yourself." } \\
\text { For Steve Social, telling authorities about } \\
\text { Burt's false testimony in the prior case } \\
\text { is: }\end{array}$ \\
\hline
\end{tabular}

Note. Participants were asked to rate status of protagonist's action on 7-point scale, anchored at $1=$ forbidden, $4=$ permitted, $7=$ required. Each participant was randomly assigned to one version of each item (Attorney vs. Non-Attorney, High Affect vs. Low Affect).

considerations (e.g., fairness and harm); and (c) have relatively clear answers under consensus rules of legal ethics (as represented in the ABA's Model Rules of Professional Conduct and the American Law Institute's Restatement (Third) of the Law Governing Lawyers). Table 1 provides a brief description of the scenarios in the instrument. The full text of all 15 scenarios is available in our supporting information file on the GEORGETOWN JOURNAL OF LEGAL ETHICS website.

We manipulated each item in two of three ways. First, for each item we varied the affective description of the scenario in ways that did not change the status of the protagonist's actions under the rules of legal ethics. (We discuss the method by which we manipulated affect and the results of this manipulation in Appendix 1.) For 11 of the 15 items, we also varied the description of the protagonist's professional role. In the attorney condition, the protagonist was described as an attorney. In the non-attorney condition, the protagonist was described as occupying another professional role (e.g., psychiatrist, accountant, physician, corporate executive).$^{57}$ An example of this manipulation for the item concerning the decision to disclose client perjury (PERJURY) is provided in Table 2a.

57. For several items, we altered certain details of the scenario in order to make the non-attorney version more realistic. Otherwise, the items used similar phrasings and differed only in the description of the professional role of the protagonist. 
Table 2b: Example of Experimental Design in Rule/StLent Items

\begin{tabular}{|c|c|}
\hline DOUBTFUL: Rule Versions & DOUBTFUL: Silent Versions \\
\hline $\begin{array}{l}\text { Larry Lawyer is defending Danny Defendant at a } \\
\text { trial for [Low Affect Version: robbery; High } \\
\text { Affect Version: robbing and pistol whipping a } \\
\text { young woman]. Danny tells Larry that he has } \\
\text { an alibi at the time of the robbery: he was at } \\
\text { home watching television with his } 90 \text { year-old } \\
\text { grandmother, Ginny. Ginny confirms this story } \\
\text { to Larry, but she is confused on some } \\
\text { important details. }\end{array}$ & $\begin{array}{l}\text { Larry Lawyer is defending Danny Defendant at a } \\
\text { trial for [Low Affect Version: robbery; High } \\
\text { Affect Version: robbing and pistol whipping a } \\
\text { young woman]. Danny tells Larry that he has an } \\
\text { alibi at the time of the robbery: he was at home } \\
\text { watching television with his } 90 \text { year-old } \\
\text { grandmother, Ginny. Ginny confirms this story } \\
\text { to Larry, but she is confused on some important } \\
\text { details. }\end{array}$ \\
\hline $\begin{array}{l}\text { Larry is pretty sure that Danny and Ginny are } \\
\text { lying about the alibi, although he does not } \\
\text { know for certain. Larry reminds them both } \\
\text { that perjury is a crime. Even so, Danny insists } \\
\text { that Ginny testify at the trial. Court rules } \\
\text { normally prohibit a lawyer from introducing } \\
\text { evidence that he knows is false. However, } \\
\text { Larry thinks he can get around this rule } \\
\text { because he does not know for certain that } \\
\text { Ginny is lying. } \\
\text { For Larry Lawyer, calling Ginny as a witness at } \\
\text { trial is: }\end{array}$ & $\begin{array}{l}\text { Larry is pretty sure that Danny and Ginny are lying } \\
\text { about the alibi, although he does not know for } \\
\text { certain. Larry reminds them both that perjury is } \\
\text { a crime. Even so, Danny insists that Ginny } \\
\text { testify at the trial. } \\
\text { For Larry Lawyer, calling Ginny as a witness at } \\
\text { trial is: }\end{array}$ \\
\hline
\end{tabular}

Note. Participants were asked to rate status of protagonist's action on 7-point scale, anchored at $1=$ forbidden, $4=$ permitted, $7=$ required. Each participant was randomly assigned to one version of each item (Rule vs. Silent, High Affect vs. Low Affect).

For four items that did not admit of an obvious formulation involving non-attorneys, we varied whether a non-controlling professional norm applied to the scenario. In the rule condition, a professional norm clearly favored (but did not compel) a particular classification for the lawyer protagonist's action. In the silent condition, no such professional norm was mentioned. Table $2 \mathrm{~b}$ provides an example of this manipulation for the item involving the lawyer's decision to introduce testimony whose veracity he doubts, but which would help exonerate his client (DOUBTFUL).

\section{RESULTS}

We present our analysis of the empirical data as responses to the questions elaborated in Part I.

\section{A. DIVERGENCE AND CONVERGENCE}

We conducted one sample t-test to examine whether (and, if so, how) the classifications of actions in legal ethics rules diverge from or converge with lay moral judgments. First, for each item, we identified how "consensus" rules of 
legal ethics would classify the actions of the lawyer protagonist. ${ }^{58}$ We then converted this classification onto the 7-point scale of our instrument to derive the "legal ethics" score, with the "legal ethics" score of 1 for actions that are forbidden under consensus legal ethics rules, of 4 for actions that are permitted under consensus rules, and of 7 for actions that are required under consensus rules. We calculated the "combined attorney" score by calculating the mean of all responses to scenarios that involved an attorney protagonist. ${ }^{59}$ For each item, we calculated divergence by running a one sample t-test to compare the "combined attorney" score with the "legal ethics" score. These results are represented in Table 3.

In sum, our results indicate statistically significant differences between the "legal ethics" and "combined attorney" scores for eleven of fifteen items. For these items, in other words, lay judgments about the status of the protagonist's action differed from the classification of that action provided by consensus legal ethics rules. For the remaining four items, there was no statistically significant difference between the "legal ethics" score and the "combined attorney" score.

In addition to analyzing statistical significance, we also compared participants' verdicts about the status of particular actions with those under consensus legal ethics rules. This is the question of "analytical significance." ${ }^{, 60}$ For any item, the difference between the "legal ethics" score and the "combined attorney" score might be statistically significant but analytically insignificant (e.g., if both scores reach the same verdict about the status of the protagonist's action). ${ }^{61}$ As indicated in Table 2, for three items the difference between the legal ethics score and the "combined attorney" score was statistically significant, but analytically insignificant. For these items the nearest verdict reached by lay moral judgments was the

58. For 14 items, we determined legal ethics classification according to the American Bar Association's Model Rules of Professional Responsibility. For the 2 items to which no ABA Model Rule applied (POTATO and CAE), we determined the legal ethics classification according to the RESTATEMENT (THIRD) OF PROFESSIONAL RESPONSIBILITY. There is, of course, much variation among jurisdictions in the content of professional responsibility rules. Our statement of a "consensus" position is meant to provide an analytic contrast, rather than to describe an actual overlap among these jurisdictions. Thanks to Sung Hui Kim for raising this point.

59. Our focus on the mean judgment of a scenario as the unit of analysis is common in empirical research on moral psychology. See, e.g., Fiery Cushman, Crime and Punishment: Distinguishing the Roles of Causal and Intentional Analyses in Moral Judgment, 108 COGNITION 353, 356 (2008) (noting that statistical treating "the mean judgment of an individual scenario as the unit of analysis . . has been employed in previous research into moral judgment"). For the 11 items that had "attorney" vs. "non-attorney" conditions, the "combined attorney" score consisted of all responses to attorney versions of the item. For the 4 items that had "rule" vs. "silent" conditions, the "combined attorney" score consisted of all responses (since every version involved an attorney protagonist).

60. We determined analytical significance in the following way: the difference between two scores is analytically significant if (a) the scores do not share a negative valence; or (b) where both scores share a positive valence, and the nearest classification for each score differs (e.g., one score most nearly classifies the action as permitted, the other as required).

61. This possibility is, in part, because "combined attorney" scores were determined on a 7-point scale, while "legal ethics" could only be represented by 1,4 , or 7 . 
TAble 3: Comparison of "Legal Ethics" Scores and "Combined ATtorney" Scores

\begin{tabular}{|c|c|c|c|c|c|c|}
\hline \multirow[b]{2}{*}{ Item } & \multicolumn{2}{|c|}{ "Legal Ethics" rules } & \multicolumn{2}{|c|}{$\begin{array}{c}\text { "Combined Attorney" } \\
\text { conditions }\end{array}$} & \multirow[b]{2}{*}{$\mathbf{t}$} & \multirow[b]{2}{*}{ p (2 tail) } \\
\hline & Score & Classification & $\begin{array}{c}\text { Score } \\
\text { (s.error) }\end{array}$ & Classification & & \\
\hline HARD & 1 & Forbidden & $4.5(.22)$ & Permitted & 15.52 & $<.001$ \\
\hline CROSS-EX & 4 & Permitted & $3.31(.16)$ & Forbidden & -4.24 & $<.001$ \\
\hline DOUBTFUL & 4 & Permitted & $4.09(.13)$ & Permitted & 0.72 & 0.23 \\
\hline CANDOR & 1 & Forbidden & $4.85(.17)$ & Permitted & 5.14 & $<.001$ \\
\hline $\mathrm{CAE}$ & 4 & Permitted & $3.92(.29)$ & Forbidden & -0.26 & 0.60 \\
\hline PATCOUN & 7 & Required & $6.03(.21)$ & Required & -4.53 & $<.001$ \\
\hline SELECT & 4 & Permitted & $4.14(.21)$ & Permitted & 0.66 & 0.25 \\
\hline POTATO & 1 & Forbidden & $3.74(.19)$ & Forbidden & 14.78 & $<.001$ \\
\hline SPAULD & 4 & Permitted & $5.94(.19)$ & Required & 10.16 & $<.001$ \\
\hline PLEASANT & 1 & Forbidden & $5.09(.31)$ & Permitted & 13.23 & $<.001$ \\
\hline PERJURY & 1 & Forbidden & $4.44(.30)$ & Permitted & 11.37 & $<.001$ \\
\hline FRAUD1 & 4 & Permitted & $5.62(.19)$ & Required & 8.49 & $<.001$ \\
\hline FRAUD2 & 4 & Permitted & $5.98(.16)$ & Required & 12.01 & $<.001$ \\
\hline SCREEN & 4 & Permitted & $4.05(.19)$ & Permitted & 0.30 & 0.38 \\
\hline ACQCOI & 1 & Forbidden & $3.24(.17)$ & Forbidden & 13.19 & $<.001$ \\
\hline
\end{tabular}

"Combined Attorney" score is mean participant response about the moral status of protagonist's action on 7-point scale, anchored at 1 (action is morally forbidden), 4 (permitted), and 7 (required), for all versions of each item that involved a lawyer protagonist. "Legal Ethics" score is status of lawyer's action under consensus rules of legal ethics converted to 7-point scale, with $1=$ action is forbidden, $4=$ action is permitted but not required, $7=$ action is required.

same as the verdict under legal ethics rules. Thus, for seven of fifteen items, legal ethics rules either reached the same verdict on the protagonist's action or were statistically indistinguishable from the mean response.

On eight items, the difference between legal ethics and lay judgments was both statistically and analytically significant. For five of these items (HARD, CROSS-EX, CANDOR, PLEASANT, PERJURY), legal ethics rules and lay judgments disagreed about the permissibility of the protagonist's action. For three other items (FRAUD1, FRAUD2, SPAULD) legal ethics rules were laxer than lay judgments, deeming permissible an action that the mean participant thought to be required. We examine these items in turn.

HARD involved whether (against a client's instructions) an attorney could decline to take advantage of a counterpart's personal misfortune to advance the client's interest in business negotiations. The mean response judged the attorney to be permitted to grant an extension to the opponent whose attorney had suffered a personal misfortune $($ mean $=4.5)$ while under the circumstances legal ethics 
rules would forbid the attorney to grant the extension. ${ }^{62}$

CROSS-EX asked whether, in order to exonerate his client, a criminal defense attorney may or must cross-examine a truthful rape witness based on humiliating information from the witness's past as a way of discrediting her testimony. ${ }^{63}$ The mean response was that attempting cross-examination is impermissible (3.32), while legal ethics rule would permit (but not require) the lawyer to attempt such a cross-examination under these circumstances. ${ }^{64}$

CANDOR involved the extent of the lawyer's duty to reveal information to a tribunal. In this scenario, a criminal defendant has pled guilty and awaits sentencing. Because of a computer glitch, the trial court judge mistakenly believes that the defendant had no prior criminal record. As a result, the judge indicates that he will sentence the defendant to probation, rather than a prison term. Participants were asked whether the criminal defense attorney has a duty to correct the judge's mistake, even though doing so would increase the likely sentence for her client. Under these circumstances, legal ethics rules would forbid the lawyer's disclosing this information because it would impart a client confidence (in violation of ABA Model Rule 1.6), and the lawyer's normal duty of candor toward the court is not triggered because the mistake did not arise from the lawyer or her client. ${ }^{65}$ However, the mean response judged disclosure to be permitted (4.86).

In PLEASANT, a client on trial for murder told his criminal defense attorney in confidence that he had previously committed two other killings for which the bodies were never recovered. The mean response judged the lawyer to be permitted to disclose the location of these bodies to authorities despite the client's insistence on confidentiality (5.09). By contrast, legal ethics rules would forbid such a disclosure over the client's objection because the lawyer learned the

62. Based on the wording of the scenario, granting the extension is prohibited because the decision to grant the extension affects the well-being of a third-party and the lawyer lacks authorization to grant the extension. Thus, the decision falls within the ambit of the client's control under Model Rule 1.2, which grants clients authority "regarding such questions as the expense to be incurred and concern for third persons who might be adversely affected." Also, the decision to grant the extension affects the client's rights regarding dismissal, which places it in the ambit of the client's control under Model Rule 1.2. Thus, HARD involves an exception to the general principle that the client controls the ends of representation, while the lawyer controls the means. Thanks to Sung Hui Kim for urging clarification of this point.

63. This scenario was an amalgamation of the examples discussed in LUBAN, LAWYERS AND JUSTICE, supra note 25, at 150, and David Luban, Partisanship, Betrayal and Autonomy in the Lawyer-Client Relationship: A Reply to Stephen Ellmann, 90 Colum. L. REv. 1004, 1025-30 (1990).

64. The tactic would not be required because the lawyer's duty to diligently represent the client's interest "does not require the use of offensive tactics or preclude the treating of all persons involved in the legal process with courtesy and respect." MODEL RuLES R. 1.3, cmt. 3. The tactic of harshly cross-examining the truthful witness would be permitted under the lawyer's "wide latitude . . . in examining an adverse witness," even one that the lawyer believes to be telling the truth. See RESTATEMENT (THIRD) OF LAW GOVERNING LAWYERS $\$ 106$ cmt. c.

65. Model Rules R. 3.3. Many state analogues to Model Rule 3.3 impose a more stringent duty of candor on attorneys. 
information in the course of representation (thus triggering the duty of confidentiality under Model Rule 1.6), and none of the exceptions that might permit disclosure would apply.

In PERJURY, a criminal defense lawyer learns that his client had perjured himself in previous criminal proceedings. The mean response found the lawyer to be permitted to disclose this information to authorities (4.44), legal ethics rules would forbid such a disclosure of a client's prior crime because the lawyer has a prima facie duty to maintain this confidence (under Model Rule 1.6), and none of the exceptions that might permit disclosure would apply.

FRAUD1 and FRAUD2 both involved an attorney confronted with the decision about whether to reveal a client's fraud in connection with the sale of art. The question in FRAUD1 concerned whether the attorney should reveal the client's prior sale of counterfeit art, while in FRAUD2 the question concerned revelation of fraud in an upcoming transaction. (Both transactions involved the attorney's services.) In both FRAUD1 and FRAUD2, the mean participant judged revelation to be required (5.62 and 5.98, respectively), while legal ethics rules would classify revelation in both cases as optional. ${ }^{66}$

Finally, SPAULD asks about the disclosure of imminent harm to a non-client utilizing a version of Spaulding v. Zimmerman ${ }^{67}$ In the course of representing an insurance company in a personal injury suit, an attorney learns that the plaintiff's has suffered injuries that are more serious than the plaintiff or his counsel realize and for which a delay in treatment could have adverse health consequences. Because revealing this information would significantly increase the value of the plaintiff's claim, the client orders the attorney not to reveal this information to the plaintiff. The average response deemed revelation to be required (5.94), while revelation would be optional under consensus legal ethics rules. ${ }^{68}$

Our findings shed light on the four hypotheses about divergence and its direction that we described in Section 1.1. Our findings do not support the global divergence hypothesis: the responses to four of the 15 items reflected no statistically significant difference from the consensus legal ethics classification, and for seven other items the closest classification was the one provided by the consensus legal ethics rules. Our results are also inconsistent with the global convergence hypothesis, since legal ethics scores and lay judgments disagreed about permissibility of a lawyer's action on five items.

Our results are consistent with the domain-specific divergence hypothesis, or

66. In both scenarios, the attorney's conduct would fall under Model Rule 1.6(b)(3), which provides that a lawyer "may reveal" client confidences in order to "prevent, mitigate or rectify substantial injury to the financial interests or property of another that is reasonably certain to result or has resulted from the client's commission of a crime or fraud in furtherance of which the client has used the lawyer's services."

67. 116 N.W.2d 704 (Minn. 1962).

68. Disclosing this information about the plaintiff's medical condition would be optional because the attorney has a reasonable belief that revelation is "necessary to prevent reasonably certain death of substantial bodily injury." MODEL Rules R. 1.6(b)(1). 
the view that legal ethics and ordinary morality diverge in some domains but notusb others. In particular, our findings support the conclusion that legal ethics rules regarding the advocacy on behalf of a client's interests diverge from lay moral judgments. For three of four items concerning advocacy ethics (HARD, CROSS-EX, and CANDOR) lay judgments diverged from legal ethics rules. Each of these items involved a scenario where, from the perspective of the attorney, furthering the client's interest would either result in harm to an identifiable third party (HARD, CROSS-EX) or else reach an undeserved legal outcome for the client (CANDOR). One way to explain these results is that lay judgments do not support the "principle of partisanship," or the notion that a lawyer advocating on behalf of a client "must be committed to the aggressive and single-minded pursuit of the client's objectives." 69

Likewise, divergence was realized on two of five items concerning confidentiality (PERJURY and PLEASANT). For both of these items, the mean response judged it permitted (but not required) for a lawyer to disclose client confidences in order to help a third party (and, in PERJURY, also helping to correct a miscarriage of justice). However, in both scenarios, disclosure was forbidden under legal ethics rules because none of the exceptions to the general requirement that a lawyer maintain client confidences under Model Rule 1.6 were implicated. For three more items (SPAULD, FRAUD1, FRAUD2) legal ethics rules would see disclosure of a client confidence to be optional, while participants judged it on average to be required. One way to interpret these findings about confidentiality, then, is that lay judgments deem it morally permitted and required for a lawyer to disclose client confidences to prevent serious harms to third parties in a broader range of circumstances than are currently recognized under the consensus rules of legal ethics. ${ }^{70}$

By contrast, in the domain of conflicts of interest, the mean response reached the same verdict as legal ethics regarding requirements about the resolution of acquired conflicts of interest (ACQCOI) ${ }^{71}$ and the permissibility of client screening to avoid certain concurrent conflicts (SCREEN) ${ }^{72}$

69. DARE, supra note 7 , at 5 .

70. These findings about lay moral attitudes towards confidentiality accord with a prior study by Fred Zacharias, who found that between $66.7 \%$ and $91.2 \%$ of lay respondents felt that a lawyer "should disclose" a client confidence in various scenarios where disclosure would prevent some harm to third parties or to social institutions. See Fred Zacharias, Rethinking Confidentiality, 74 IowA L. Rev. 351, 395 Table V (1988).

71. Legal ethics rules prohibit concurrent conflicts of interests, even ones that arise in the course of representation. See MODEL RULES R. 1.7. The scenario in ACQCOI involved such an "acquired" conflict. For this item, the "combined attorney" score was 3.24. In other words, the mean judgment deemed the lawyer protagonist forbidden to continuing to continue with a conflicted representation.

72. The Model Rules permit lawyers at the same firm to avoid imputed disqualification based on certain concurrent conflicts of interest through the use of "nonconsensual" ethical screens. See MODEL RULES R. 1.18 (d)(2). In SCREEN, the mean respondent judged such a "screened" representation to be permitted ("combined attorney" score $=4.05$ ). Furthermore, $81 \%$ of participants judged the attomey's conduct to at least be permissible (i.e., assigned a "combined attorney" score $\geq 4$ ). 
Thus, our results are consistent with the following articulation of the domain-specific divergence hypothesis: legal ethics rules regarding advocacy and confidentiality diverge from ordinary morality because they insufficiently account for the interests of third parties, while legal ethics rules regarding conflicts of interest are consistent with ordinary morality. However, we also cannot rule out the unpatterned divergence hypothesis, or the position that there is no discernible pattern to the convergence and divergence between legal ethics rules and ordinary moral judgments. Perhaps the specific legal ethics rules about conflicts of interest that we tested cohere with ordinary moral judgments, but other rules in this domain do not. Therefore, a more comprehensive examination of the rules and/or operative principles of legal ethics generally (and those regarding conflicts of interest specifically) would be needed to discern between these two hypotheses.

Our results also suggest that the divergence between legal ethics and ordinary morality is not as large as might be supposed. For seven of fifteen items that we tested, the mean classification of the status of a lawyer's action was either statistically or analytically indistinct from the one provided by consensus legal ethics rules. If anything, our results overstate the overall divergence between legal ethics rules and ordinary morality, since we tested controversial legal ethics provisions that are widely thought to generate moral dilemmas (and so are more likely to conflict with lay moral judgments than provisions which do not create dilemmas). It is plausible, as David Luban has asserted, that "no one disagrees with the principles forbidding professionals from lying, cheating, and using their clients for their own profit and pleasure."73 Using our method, one might well find that less controversial provisions of legal ethics systematically converge with lay moral judgments. In any event, our results suggest that some core provisions of legal ethics diverge from lay judgments about what lawyers are morally permitted or required to do.

\section{B. THE LAWYER'S ROLE}

Our method can also test the significance of lawyer's role as such. Recall that, on the "lawyer distinctiveness thesis" (LDT), considerations related to the lawyer's role are necessarily relevant to the status of the lawyer's action. If LDT were true, then the description of a protagonist's role as a lawyer should be associated with differences in empirical moral judgments about the status of the protagonist's action. The "lawyer exceptionalism thesis" (LET) posits that unique normative standards apply to lawyers. LET predicts that the lawyer's role can "switch" the valence of an action, for example by permitting (or requiring) lawyers to act in ways that would be morally forbidden if done by occupants of

73. David Luban, Professional Ethics, in A Companion to Applied Ethics 583, 584 (R.G. Frey \& Christopher Heath Wellman eds., 2003). 
TABLE 4: COMPARISON OF "ATTORNEY" SCORES AND "NON-ATTORNEY" SCORES

\begin{tabular}{l|c|c|c|c|c|c}
\multirow{2}{*}{\multicolumn{1}{c}{ Item }} & \multicolumn{2}{c|}{ “Attorney" conditions } & "Non-attorney" conditions & & \\
\cline { 2 - 6 } & $\begin{array}{c}\text { Score } \\
\text { (s.error) }\end{array}$ & Classification & $\begin{array}{c}\text { Score } \\
\text { (s.error) }\end{array}$ & Classification & t & p (2 tail) \\
\hline HARD & $4.5(.23)$ & Permitted & $4.28(.18)$ & Permitted & 0.76 & 0.77 \\
\hline CAE & $3.92(.29)$ & Forbidden & $3.5(.26)$ & Forbidden & 1.09 & 0.86 \\
\hline PATCOUN & $6.03(.21)$ & Required & $5.92(.20)$ & Required & 0.38 & 0.64 \\
\hline SELECT & $4.14(.21)$ & Permitted & $4.13(.17)$ & Permitted & 0.01 & 0.50 \\
\hline SPAULD & $5.94(.19)$ & Required & $5.85(.24)$ & Required & 0.28 & 0.61 \\
\hline PLEASANT & $5.09(.31)$ & Permitted & $5.55(.25)$ & Permitted & -1.14 & 0.12 \\
\hline PERJURY & $4.44(.30)$ & Permitted & $4.47(.25)$ & Permitted & -0.07 & 0.46 \\
\hline FRAUD1 & $5.62(.19)$ & Required & $5.44(.20)$ & Permitted & 0.64 & 0.73 \\
\hline FRAUD2 & $5.98(.16)$ & Required & $5.83(.18)$ & Required & 0.60 & 0.72 \\
\hline SCREEN & $4.05(.19)$ & Permitted & $4.16(.17)$ & Permitted & -0.43 & 0.33 \\
\hline ACQCOI & $3.24(.17)$ & Forbidden & $4.07(.23)$ & Permitted & -2.92 & $\mathbf{0 . 0 0 2}$
\end{tabular}

"Attorney" score is mean response concerning status of protagonist's action on 7-point scale, anchored at 1 (action is morally forbidden), 4 (permitted), and 7 (required) for all versions of item involving lawyer protagonist. "Non-attorney" score is mean response for all versions of item involving non-lawyer protagonist.

other professional roles.

We tested LDT and LET by analyzing participants' judgments on items that involved attorney and non-attorney protagonists. For each of these 11 items, we calculated the mean classification for all versions where the protagonist was an attorney (the "attorney" score), as well as in all versions where the protagonist occupied some other professional role (the "non-attorney" score). We then analyzed the significance of the lawyer's role by performing a t-test of the attorney and non-attorney scores. If LDT is accurate, then the differences between the "attorney" and "non-attorney" score should be statistically significant. If LET is accurate, then the differences between the "attorney" and "non-attorney" scores should be both statistically and analytically significant. Our results are presented in Table 4.

For ten of eleven items, there was no statistically significant difference between the "attorney" and "non-attorney" score. In other words, lay moral judgments did not attribute a distinctive significance to the lawyer's role.

However, results for the item involving the resolution of acquired conflicts of interest (ACQCOI) are consistent with at least LDT. The scenario in this item involves a conflict between the protagonist's client and a third-party insurer who pays for the protagonist's services. In the course of serving her client, the protagonist learns information that would (if revealed to the insurer) result in the denial of coverage to the client. (In the non-attorney condition, the protagonist was described as a psychiatrist.) Participants were asked about the protagonist's 
continuing the professional relationship with the client after learning about this conflict of interest. For this item, the mean "attorney score" differed significantly from the mean "non-attorney" score $(t=-2.92 ; p=0.002)$. Results on this item are thus consistent with LDT. These results might also be consistent with LET. The mean participant judged it permissible for a psychiatrist to continue representing the client in the face of an acquired conflict of interest, but impermissible for an attorney to do so. This finding would be consistent with the notion (central to LET) that the attorney's role can "switch" the permissibility of an action. However, because the standard error for the "non-attorney" score was .22 on a seven-point scale, we cannot reject the null hypothesis that the lawyer's role was not associated with a switch in the mean verdict about the status of the protagonist's action.

Our findings do not support the conclusion that the lawyer's role has generally distinctive (let alone unique) moral significance. For ten of eleven items, the attorney's role was not associated with a statistically significant change in lay judgments about the status of an action. However, the results for one item (ACQCOI) support the attribution of a distinctive moral significance to the lawyer's role regarding the avoidance conflicts of interest. These results are also consistent with the notion that lawyers have unique responsibilities in this domain. Thus, our results can be interpreted to deny that the lawyer's role (as such) generally explains the moral status of lawyers' actions, although it might have distinctive (and perhaps unique) significance regarding conflicts of interest.

\section{PROFESSIONAL NORMS}

Our method also provides a way to test the professional norms thesis (PNT), which posits that the content of professional norms (rather than broader moral or professional values) establishes what a lawyer has reason to do. PNT predicts that professional norms not only influence judgments about the status of an action (an "amplification" effect), but also can change whether an action is judged permissible (a "switching" effect).

We tested PNT by examining items that were varied based on the presence or absence of a (non-controlling) rule of professional conduct. For these items, we calculated the mean response in all conditions where such a rule was referenced (the "rule" score), as well as in all conditions where no such rule was referenced (the "silent" score). We then compared the "rule" and "silent" scores by running a two sample t-test. If PNT is accurate, then the "rule" scores should differ significantly from the "silent" scores and judgments in "rule" conditions moving toward the classification picked out by the professional norm.

Our results are described in Table 5. For two of the four items (CANDOR and DOUBTFUL) the introduction of a professional norm was associated with a statistically significant difference in judgments towards the classification prescribed by the norm. We explore these items in greater depth. 
TABle 5: Comparison OF "Silent" ScORES ANd "Rule" Scores

\begin{tabular}{l|c|c|c|c|c|c}
\multirow{2}{*}{\multicolumn{1}{c|}{ Item }} & \multicolumn{2}{|c|}{ "Silent" conditions } & \multicolumn{2}{|c|}{ "Rule" conditions } & \multirow{2}{*}{} & \multirow{2}{*}{ "(2 tail) } \\
\cline { 2 - 6 } & $\begin{array}{c}\text { Score } \\
\text { (s.error) }\end{array}$ & Classification & $\begin{array}{c}\text { Score } \\
\text { (s.error) }\end{array}$ & Classification & $\mathbf{t}$ & p \\
\hline CROSS-EX & $3.41(.22)$ & Forbidden & $3.22(.23)$ & Forbidden & -0.59 & 0.27 \\
\hline DOUBTFUL & $4.31(.20)$ & Permitted & $3.84(.14)$ & Forbidden & -1.87 & $\mathbf{0 . 0 3}$ \\
\hline CANDOR & $4.43(.25)$ & Permitted & $5.27(.21)$ & Permitted & 2.59 & 0.99 \\
\hline POTATO & $3.38(.19)$ & Forbidden & $3.55(.18)$ & Forbidden & 0.67 & 0.74
\end{tabular}

"Rule" score is mean response concerning status of lawyer protagonist's action on 7-point scale, anchored at 1 (action is morally forbidden), 4 (permitted), and 7 (required) for all versions of item that referenced non-binding professional norm. "Silent" score is mean response for all versions of item that did not reference non-binding professional norm.

As noted above, the scenario in CANDOR involved a criminal defense attorney for whom correcting a court's mistake would likely result in a harsher sentence for the lawyer's client. In "rule" conditions, participants were informed that a professional norm usually requires a lawyer "to correct mistakes by a judge, even when the mistake benefits the lawyer's client." However, the rule did not directly control because the misapprehension arose with the court (rather than with the attorney or her client). Thus, disclosure was favored by the professional norms governing lawyers, but not strictly required by them. For both "rule" and "silent" conditions, the mean response judged the attorney's disclosure to be permitted, and the difference between these two scores was statistically significant. $(t=2.59 ; p=0.99)$. Thus, results for this item are consistent with the notion that referencing a non-controlling professional norm requiring disclosure amplified participants' judgments in favor of disclosure, as PNT would predict.

The results in DOUBTFUL support the conclusion that professional norms can "switch" the permissibility of an action. In DOUBTFUL, a criminal defense lawyer is faced with the question of whether to introduce testimonial evidence that might exonerate his client, but that the lawyer suspected to be false. In "rule" versions, participants were also informed of a norm against knowingly introducing false testimony, albeit one that did not directly control the decision because the lawyer did not know for certain that the testimony was false. In "silent" versions the mean response classified introducing this testimony as permitted (4.31), while in "rule" versions the mean response classified this action as impermissible (3.84). The difference between these scores was statistically significant. $(t=-1.87 ; p=0.03)$. These findings are thus consistent with the conclusion that introducing a professional norm against attorney's suborning false testimony changed lay moral judgments about whether the protagonist's action was permissible.

However, for the other two items (POTATO and CROSS-EX), the introduction of a professional norm was not associated with a significant change in lay 
judgments about a lawyer's action. For both items, the mean response in "rule" and "silent" versions judged the protagonist's action to be impermissible, and for both items difference between "rule" and "silent" scores was statistically insignificant. Thus, for these two items, introducing a professional norm concerning the protagonist's action was not associated with a significant change in empirical moral judgments. This finding is inconsistent with the thesis that professional norms necessarily have normative significance.

Our findings provide mixed support for the professional norms thesis. For the DOUBTFUL item, the introduction of a professional norm was associated with a "switch" in lay judgments about what a lawyer is permitted to do. The results in another item (CANDOR) may or may not be consistent with PNT. Because the applicable professional norm required disclosure, a critic might contend that "rule" scores should have been closer to 7 if PNT adequacy characterized lay judgments. Arguably, then, introducing the professional norm did not influence lay judgments enough to vindicate PNT. Moreover, results for two other items (POTATO and CROSS-EX) are inconsistent with the notion that professional norms necessarily influence lay judgments.

Thus, our results support the notion that the content of nonbinding professional norms can sometimes affect (and perhaps even change) the moral status of a lawyer's actions. These results do not prove or disprove the professional norms thesis; doing so would require much more investigation. ${ }^{74}$ That said, our results challenge a strong form of PNT, namely that a lawyer can determine what to do in any particular case by following Michael Davis's maxim to "obey your profession's code."75 Pace Davis, our results do not support the view that professional norms generally provide a resolution to the practical question of what to do, since there appear to be some questions for which professional norms make no moral difference.

\section{IMPLiCATIONS AND Future RESEARCH}

In summary, our results illuminate three important questions about legal ethics. First, our findings suggest that legal ethics rules diverge from ordinary moral judgments about the professional actions of lawyers. However, this divergence is not systematic. Rather, it is either domain-sensitive (realized in the domains of

74. For example, vindicating PNT would require more elaboration of the circumstances under which a professional norm can forbid the lawyer from performing an otherwise impermissible action. It would also require evidence that a norm permitting an action could permit a lawyer to act in ways that would otherwise be impermissible. Vindicating PNT would also require establishing the conditions under which a professional norm has an amplification effect. Also, our results do not clearly distinguish PNT from rival theses, some of which assign predominant significance to professional values associated with the lawyer's role, and others broader moral values implicated by this role. Finally, our results do not rule out an asymmetric version of PNT, on which professional norms have different effects on actions that are antecedently permitted than on actions that are antecedently forbidden.

75. DAvis, supra note 47 , at 26. 
advocacy ethics and confidentiality) or else arises haphazardly. Second, our results indicate that ordinary moral judgments do not generally assign distinctive significance to the lawyer's role as such. Nor do lay judgments generally classify the moral status of lawyers' actions differently from those of other professionals in analogous circumstances. However, we find support for a distinctive significance to the lawyer's role regarding the resolution of conflicts of interest, and we cannot rule out that the lawyer's role imposes unique moral requirements in this domain. Third, our results do not support the conclusion that the professional norms governing lawyers necessarily determine what a lawyer has most reason to do. Our findings do suggest that the content of professional norms can influence lay judgments about the moral status of a lawyer's action. Further, we cannot rule out that professional norms have the capacity to "switch" the moral valence of actions-that is, to make impermissible actions that would otherwise be permitted.

Our findings have important implications for many central questions about legal ethics, including debates about which rules should govern the professional conduct of lawyers. However, in the absence of a theory about why moral justification matters to legal ethics, it is difficult to draw direct policy conclusions. As Seana Shiffrin contends, it is not necessarily problematic that legal rules diverge from generally applicable moral norms. Establishing this conclusion requires a substantive argument for what the relationship between law and morality should be. ${ }^{76}$ More specifically, one might deny that specific legal ethics rules need to converge with ordinary moral judgments in order for lawyer's professional actions to be morally justified. ${ }^{77}$ One might also deny that moral justification is central to justifying rules of legal ethics. ${ }^{78}$ Furthermore, there are methodological barriers to drawing broad conclusions about legal ethics rules from our results. Our survey might have gauged participants" "pre-theoretic intuitions," rather than their "considered judgments." ${ }^{\text {"79 }}$ Legal ethics rules are the product of sustained reflection and debate. It is possible, therefore, that our findings about divergence would change if participants had spent as much time

76. Seana Valentine Shiffrin, The Divergence of Contract and Promise, 120 HARv. L. REv. 708, 737-39 (2007). Shiffrin goes on to argue, based on concern for preserving moral agency, that "we should be concerned about law's assigning significantly different normative valences and expectations to practices that bear strong similarity to moral practices, especially if we expect both practices to occur frequently and often along-side each other." Id. at 741 .

77. See, e.g., Stephen Ellmann, Lawyering for Justice in a Flawed Democracy, 90 CoLuM. L. REv. 116, 138-41 (1990) (proposing that lack of direct moral justification for lawyer's professional responsibilities need not entail moral illegitimacy of lawyer's professional actions).

78. See Geoffrey Hazard, Jr. \& Dana Remus, Advocacy Revalued, 159 U. PA. L. Rev. 751, 754-55 (2011) (articulating method of normative "evaluat[ion of] the role of the advocate by reference to a political need for authoritative dispute resolution"); Daniel Markovits, Three Issues in Legal Ethics, 60 U. ToR. L.J. 1003, 1010 (2010) ("Legal ethics . . . cannot . . . ever be reduced to generic moral or political theory.").

79. Our use of these terms is meant to mirror their usage in John Rawls's description of "reflective equilibrium." See JoHn RaWLs, A THEORY OF JuSTICE § 9 (Rev. Ed. 1999). 
reflecting on these issues as lawyers and professional ethicists do ${ }^{80}$ Likewise, our survey participants were mostly advanced university undergraduates; it is uncertain whether their patterns of response are representative of the population at large.

That said, our findings are helpful for assessing specific rules of professional responsibility. Consider recent amendments to the American Bar Association's Model Rules of Professional Conduct regarding the maintenance of client confidences. In 2003, revisions to the Model Rules expanded the circumstances under which a lawyer may reveal information that she learns in the course of legal representation. Under these amendments, a lawyer is permitted (but not required) to reveal client confidences when revelation is believed necessary to prevent a client from committing a crime or fraud in which the lawyer's services were utilized. ${ }^{81}$ In response to two scenarios involving client fraud (FRAUD1 and FRAUD2), the mean participant judgment was that revelation was required. One can infer that the 2003 amendments better aligned confidentiality rules with ordinary morality, thus fulfilling the ABA's goal of reducing the degree to which the Model Rules "lagg[ed] . . behind society generally." also support the conclusion that these amendments did not go far enough. The 2003 amendments deemed revelation of client confidences to be optional in situations where the average participant judged it to be morally required. Moreover, participants deemed revelation to be permitted in scenarios where it would be forbidden under current legal ethics rules. Thus, our results suggest that expanding the contexts where revelation is permitted and/or required could further reduce the divergence between legal ethics and ordinary morality.

Our results have significant implications for ongoing theoretical debates about legal ethics. Some theories of legal ethics are premised on the global divergence hypothesis, or the view that legal ethics differ in general from ordinary morality. Nearly every theory of legal ethics presumes that the lawyer's role has distinctive normative significance. Further, many theories of legal ethics presume the truth of the lawyer exceptionalism thesis, the professional norms thesis, or both. Because our findings do not unambiguously support any of these theses, they challenge whether the substantive theories based on them accurately describe our normative landscape.

Our results also provide indirect support for so-called "moral activist" theories

80. Thanks to Bill Simon for raising this last point.

81. More precisely, Model Rule 1.6(b)(2) permits revelation where the lawyer believes it is necessary "to prevent the client from committing a crime or fraud that is reasonably certain to result in substantial injury to the financial interests or property of another," and for which the client has utilized the lawyer's legal services. Model Rule 1.6(b)(3) permits disclosure in order to "prevent, mitigate, or rectify substantial injury to the financial interests or property of another that is reasonably certain to result or has result from the client's commission of a crime or fraud in furtherance of which the client has used the lawyer's services."

82. David W. Raack, The Ethics 2000 Commission's Proposed Revision of the Model Rules: Substantive Change or Just a Makeover, 27 OHı N.U.L. REv. 233 (2000). 
of legal ethics ${ }^{83}$ by illuminating the degree to which "common morality ... contain[s] adversarial elements," which some proponents of these theories take to be a significant open question. ${ }^{84}$ Our findings are consistent with the view that moral principles are sensitive to adversarial settings, but only to a limited extent (and not nearly as much as is supposed by so-called "hired gun" theories of legal ethics) ${ }^{85}$ Our findings undermine some of the most prominent objections to "moral activist" views, including W. Bradley Wendel's charge that "justified roles are relatively nontransparent to moral analysis." ${ }^{86}$ Our findings are more consistent with the notion the lawyer's role $i$ s transparent to moral analysis, in the sense that moral judgments seem capable of reaching intelligent conclusions regarding the ethical challenges that lawyers face. However, our results indicate that moral analysis does not vindicate all (or even central) tenets of legal ethics.

Future research could solidify our findings in several respects. First, surveying a more demographically representative sample would allow more robust inferences about the content of lay moral judgments about legal ethics and the specific effects of professional roles and professional norms. Second, testing a wider range of rules and principles within the various domains of legal ethics would more clearly distinguish whether divergence is domain-specific or unpatterned. Third, one could test PNT more directly by examining the comparative effect of norms in favor of and against actions that are antecedently permissible, as well as by comparing the influence of different norm operators (e.g., "ought" vs. "must") on empirical moral judgments about legal ethics. ${ }^{87}$

Our research can also be extended in a number of fruitful ways. Future research could examine other factors that are commonly thought to bear on the justification for a lawyer's professional actions. Perhaps lay judgments about what lawyers should be permitted or required to do track judgments about the justification for particular legal rules or the legal system as a whole.$^{88}$ Perhaps

83. See generally LUBAN, Legal ETHICS AND Human DignITY, supra note 6; RHODE, IN THE INTERESTS of Justice, supra note 6.

84. Luban, supra note 73 , at 592 .

85. "Hired gun" theories are characterized by their advancement of the principles of partisanship (or the notion that "[w]ithin, but all the way up to, the limits of the law, the lawyer is committed to the aggressive and single-minded pursuit of the client's objectives"), neutrality (which dictates that the lawyer must not allow his own view of the moral status of the client's objectives or character to affect the diligence or zealousness with which he pursues the client's lawful objectives), and non-accountability (which exempts lawyers from the normal moral practice of judging someone to have acted immorally if he has knowingly and deliberately helped another to act immorally). See DARE, supra note 7, at 5-10. For the advocate of the "hired gun" view, these principles entail that generally applicable moral constraints do not apply to the adversarial settings in which many lawyers operate. $I d$. at 13.

86. W. BRADLEY WENDEL, LAWYERS AND FIDELITY TO LAW 26 (2010).

87. See Brian Sheppard \& Fiery Cushman, Evaluating Norms: An Empirical Analysis of the Relationship Between Norm-Content, Operator, and Charitable Behavior, 63 VAND. L. REv. 55 (2010) (finding interactions between norm content and norm operators in patterns of charitable behavior among experimental subjects).

88. See, e.g., Rodes, Jr., supra note 40, at 991 (arguing that, given their "discernment of the injustice of the death penalty," lawyers in death penalty cases are justified in adopting dilatory tactics that would not be justified 
these judgments vary across substantive areas of legal practice, ${ }^{89}$ contexts of legal representation, ${ }^{90}$ or based on the fundamental importance of the client's interest at stake. ${ }^{91}$

In any event, the experimental methodology elaborated here provides a powerful way to examine disputed empirical propositions about legal ethics. This method can illuminate many of the most important theoretical and policy questions facing the legal profession, as well as some of the most vexing practical questions that lawyers face in their everyday professional lives.

\section{APPENDIX 1: AfFECTIVE MANIPULATIONS AND RESUltS}

We manipulated the affective description of each item in our instrument. This manipulation was undertaken in order to rule out that participants' answers were primarily responding to emotional cues in a scenario. Many philosophers and psychologists contend that emotional or affective considerations are sufficient to generate moral judgments. ${ }^{92}$ On these models, lay moral judgments about the status of lawyers' actions would be expected to respond primarily to affective considerations, even irrelevant ones. By contrast, on so-called rationalist models,

in other contexts of representation). The notion that judgments about legal ethics derive from judgments about the justification for the legal system is consistent with Gregory Mitchell and Philip Tetlock finding of a link between judgments about specific tort law doctrines and information about the overall justness of the legal system. See Gregory Mitchell \& Philip E. Tetlock, An Empirical Inquiry into the Relation of Corrective Justice to Distributive Justice, 3 J. EMPIRICAL Legal STUD. 421 (2006).

89. See Wilkins, supra note 25 , at 517 (arguing that legal ethics principles should be sensitive to factors like task, subject matter, status, type of lawyer, and type of client); Lynn M. Mather \& Leslie C. Levin, Epilogue, in Lawyers in Practice: Ethical Decisionmaking in Context 365 (Lynn M. Mather \& Leslie C. Levin eds., 2012) (summarizing sociological research on lawyers' ethical decision making to conclude that important contextual factors include type and wealth of clients, content of substantive or procedural law, enforcement mechanisms, and lawyers' individual and collective perceptions of legal system and law's morality).

90. See Alexander Guerrero, Lawyers, Context, and Legitimacy: A New Theory of Legal Ethics, 25 GEo. J. LEGAL ETHICS. 107, 109-10 (2012) (defending the "Multi-Context View," under which justification for lawyer's professional action varies based on whether lawyer is defending individual against threat of state action).

91. See WENDEL, supra note 86 , at 85 ("Criminal defense is different, because of the importance of the defendant's procedural entitlements, such as the presumption of innocence, the requirement that the state prove its case beyond a reasonable doubt, the privilege against self-incrimination, and the privacy and dignitary interests protected by constitutional doctrines governing police investigations.").

92. See, e.g., Jonathan Haidt, The Emotional Dog and its Rational Tail: A Social Intuitionist Approach to Moral Judgment, 108 PSYCHOL. REv. 814, 817 (2001) (describing "social intuitionist" model of moral judgments, according to which "moral judgment is caused by quick moral intuitions and is followed (when needed) by slow, ex post facto moral reasoning"); Jesse Prinz, The Emotional Basis of Moral Judgments, 9 PHIL. EXPLORATIONS 29 (2006) (defending sentimentalist model of moral judgments, under which "emotions are not merely correlated with moral judgments but they are also, in some sense, both necessary and sufficient"); Joshua D. Greene, The Secret Joke of Kant's Soul, in Moral Psychology, Vol. 3: The Neuroscience of Morality: EMotion, Disease, AND DeVElopment 35 (Walter Sinnott-Armstrong ed., 2008) (arguing that "deontological judgments tend to be driven by emotional responses, and that deontological philosophy, rather than being grounded in moral reasoning, is to a large extent an exercise in moral rationalization," while "consequentialism . . . arises from rather different psychological processes, ones that are more 'cognitive,' and more likely to involve genuine moral reasoning"). 
moral judgments are seen as responding to cognitive considerations (like principled commitments). ${ }^{93}$ If (consistently with anti-rationalist models) affective considerations predominated in participants' responses, then one might doubt whether participants' responses provide good evidence for the contours of "ordinary morality."

To test for affective primacy, we manipulated the affective description of each item in one of three ways. For five scenarios (DOUBTFUL, CANDOR, PLEASANT, SCREEN and ACQCOI), we varied the description of the circumstances in ways that would typically elicit more or less "integral" anger, ${ }^{94}$ which has been found to "influence judgments related to matters of justice." 95 For these items, high affect versions were designed to elicit more anger about the protagonist's action, while low affect versions were designed to elicit less. For eight scenarios (HARD, CROSS-EX, SELECT, POTATO, SPAULD, PERJURY, FRAUD1, and FRAUD2), we altered the amount or seriousness of the harms to others. These manipulations should affect moral judgments by eliciting greater or lesser amounts of sympathy for the person(s) affected by the protagonist's actions. ${ }^{96}$ For these items, high affect versions were designed to elicit more sympathy for those who would be affected by the protagonist's action, while low-affect versions were designed to elicit less. For two scenarios (CAE and PATCOUN), we manipulated whether the description of the interests affected by the protagonist's actions was abstract or concrete. Previous research has found that concrete descriptions of vignettes produced greater affective responses. ${ }^{97}$ For these items, high affect versions more concretely described the likely effects of or considerations related to the protagonist's action, while low-affect versions described these likely effects or considerations more abstractly.

For each item, we established a "high affect" score by calculating the mean classification in all high-affect versions of the item that involved a lawyer

93. See, e.g., Bryce Huebner, Susan Dwyer \& Mark Hauser, The Role of Emotion in Moral Psychology, 13 TrENDS IN COG. SCI. 1, 5 (2009) (arguing that experimental evidence "is insufficient to support the hypothesis that emotional processes mediate our intuitive moral judgments, or that our moral concepts are emotionally constituted" but rather supports the hypothesis that "our moral judgments are mediated by a fast, unconscious process that operates over causal-intentional representations" of actions); Hanno Sauer, Social Intuitionism and the Psychology of Moral Reasoning, 6 PHIL. CoMPASS 708, 719 (2011) (summarizing experimental findings to find that " $[\mathrm{t}]$ he role played by conscious reasoning ... is to make explicit the normative reasons that (would) justify our judgments and that did play a causally effective role in the acquisition, formation and maintenance, in short: the education of our moral intuitions").

94. E. J. Horberg, et al., Disgust and the Moralization of Purity. 97 J. PERS. \& Soc. PsYCHOL. 963, 966 (2009) (describing "integral emotion" effects as where "the emotion elicited by a particular event influences judgments made about that same event").

95. Elizabeth J. Horberg, Christopher Oveis \& Dacher Keltner, Emotions as Moral Amplifiers: An Appraisal Tendency Approach to the Influences of Distinct Emotions upon Moral Judgment, 3 Emotion Rev. 237, 240 (2011).

96. Id. at 238 , table 1 .

97. Shaun Nichols \& Joshua Knobe, Moral Responsibility and Determinism: The Cognitive Science of Folk Intuitions, 41 Nous 663, 668-71 (2007). 


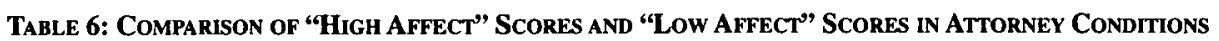

\begin{tabular}{|c|c|c|c|c|c|c|}
\hline \multirow[b]{2}{*}{ Item } & \multicolumn{2}{|c|}{ "Low Affect" conditions } & \multicolumn{2}{|c|}{ "High Affect" conditions } & \multirow[b]{2}{*}{$\mathbf{t}$} & \multirow[b]{2}{*}{ p (2 tail) } \\
\hline & $\begin{array}{c}\text { Score } \\
\text { (s.error) }\end{array}$ & Classification & $\begin{array}{c}\text { Score } \\
\text { (s.error) }\end{array}$ & Classification & & \\
\hline HARD & $4.03(.21)$ & Permitted & $5(.20)$ & Permitted & -2.21 & 0.02 \\
\hline CROSS-EX & $3.2(.21)$ & Forbidden & $3.38(.24)$ & Forbidden & -0.40 & 0.34 \\
\hline DOUBTFUL & $4(.18)$ & Permitted & $4.18(.19)$ & Permitted & -0.71 & 0.24 \\
\hline CANDOR & $4.75(.23)$ & Permitted & $4.98(.24)$ & Permitted & -0.69 & 0.25 \\
\hline CAE & $3.73(.28)$ & Forbidden & $4.11(.27)$ & Permitted & -0.66 & 0.26 \\
\hline PATCOUN & $5.89(.19)$ & Required & $6.2(.22)$ & Required & -0.72 & 0.24 \\
\hline SELECT & $3.76(.18)$ & Forbidden & $4.56(.19)$ & Permitted & -1.90 & 0.03 \\
\hline POTATO & $3.46(.19)$ & Forbidden & $3.47(.18)$ & Forbidden & -0.02 & 0.49 \\
\hline SPAULD & $5.96(.21)$ & Required & $5.92(.29)$ & Required & 0.11 & 0.54 \\
\hline PLEASANT & $5.24(.29)$ & Permitted & $4.96(.28)$ & Permitted & 0.45 & 0.67 \\
\hline PERJURY & $4.17(.25)$ & Permitted & $4.75(.29)$ & Permitted & -0.94 & 0.18 \\
\hline FRAUDI & $5.5(.28)$ & Required & $5.74(.26)$ & Required & -0.63 & 0.27 \\
\hline FRAUD2 & $6.11(.19)$ & Required & $5.85(.27)$ & Required & 0.80 & 0.79 \\
\hline SCREEN & $3.92(.19)$ & Forbidden & $4.18(.16)$ & Permitted & -0.70 & 0.24 \\
\hline ACQCOI & $3.44(.22)$ & Forbidden & $3.03(.19)$ & Forbidden & 1.20 & 0.88 \\
\hline
\end{tabular}

"Low Affect" score is mean response concerning status of lawyer protagonist's action on 7-point scale, anchored at 1 (action is morally forbidden), 4 (permitted), and 7 (required) for all versions of item that involved low affect description of scenario. "High Affect" score is mean response for all versions of item that involved high affect description of scenario

protagonist, and a "low affect" score by calculating the mean classification for all low-affect versions that involved a lawyer protagonist. We then performed an unpaired t-test of the "high affect" score and "low affect" score, the results of which are presented in Table 6.

Our results are inconsistent with the notion that participants' judgments were primarily responses to emotional cues. For $1 \dot{3}$ of 15 items, we found no statistically significant difference between the "high affect" score and the "low affect" score. In other words, manipulation of the affective description of a scenario was not associated with a significant difference in the mean response. For two items (HARD and SELECT), variation in the affective description of the scenario was associated with a statistically and analytically significant difference in the mean response. Figures $1 \mathrm{a}$ and $1 \mathrm{~b}$ describes the results for all conditions of HARD and SELECT.

While responses to these items suggest an influence of affective considerations, the response to HARD do not unambiguously support the conclusion that affective considerations predominated. HARD involved a protagonist who 


\section{Figure 1a: Comparison of high affect vs. low affect scores for attorney and non-attorney conditions of HARD*}

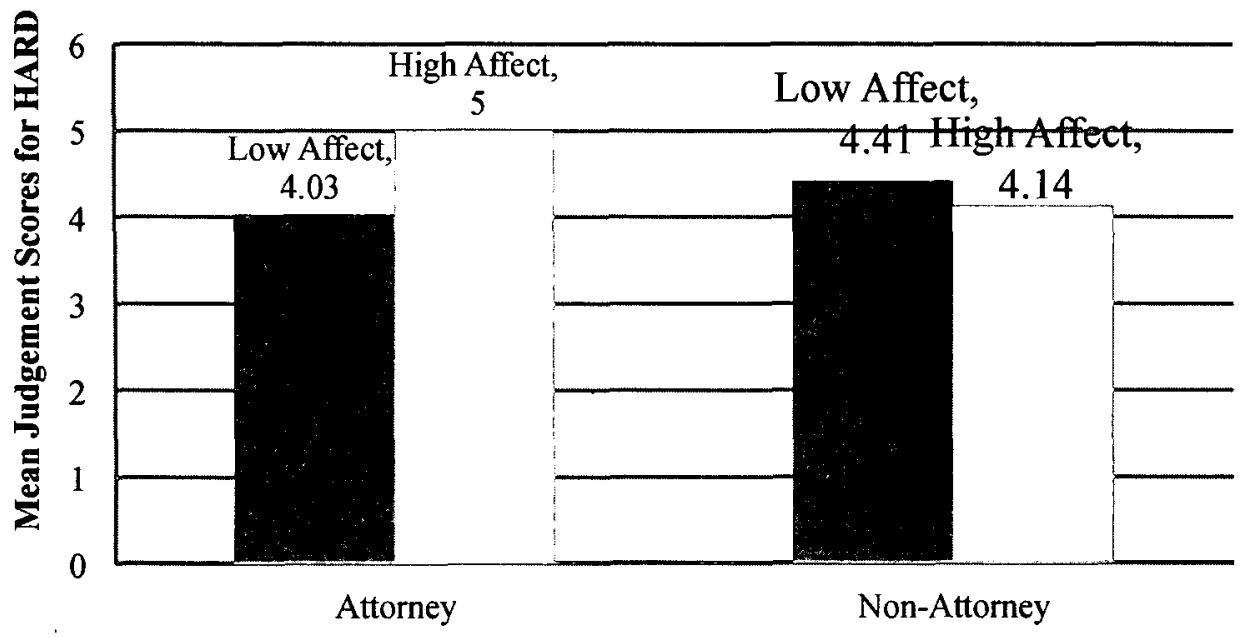

* Two sample t-tests show significant difference between the high vs. low affect mean scores for attorney situations $(\mathrm{p}=.03)$, and non-significant difference for non-attorney situations $(\mathrm{p}=.46)$.

(having been instructed by his client to drive the hardest bargain possible) is presented with an opportunity to take advantage of a counterpart's personal misfortune in business negotiations. In high-affect versions the counterpart's misfortune was the unexpected loss of a child, while in low-affect versions the misfortune was a minor heart attack. The results in HARD exhibit a statistically significant difference between responses in high-affect and low-affect conditions for versions involving an attorney protagonist, but not for items when the protagonist was a corporate executive. These results do not necessarily support either an anti-rationalist or rationalist model, since it is possible that (consistent with rationalism) the description of the protagonist's role mediated the influence of emotional factors.

In SELECT, by contrast, the distinction between high-affect and low-affect scores was similar in both attorney and non-attorney conditions: the mean participant judged it permissible for the protagonist to undertake representation in high-affect condition and impermissible in low affect condition. The high affect version of SELECT involved the protagonist's discrimination against prospective clients based on an attitude that respondents were unlikely to share, namely the view that interracial relationships were morally wrong. The low affect version involved discrimination based on attitudes that respondents were more 


\section{Figure 1b: Comparison of high affect vs. low affect scores for attorney and non-attorney versions of SELECT*}

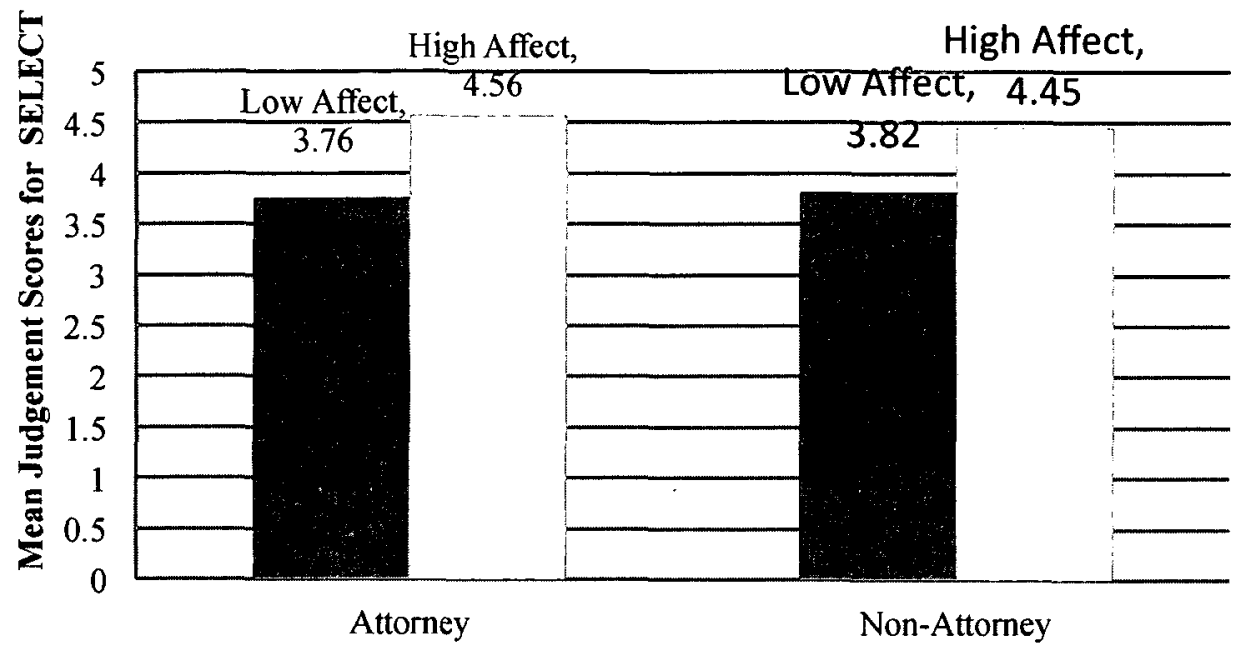

* Two sample t-tests show significant difference between the high vs. low affect mean scores for attorney situations $(p=.06)$, and non-significant difference for non-attorney situations $(\mathrm{p}=.07)$

likely to share: the view that incestuous relationships are morally wrong. ${ }^{98}$ One interpretation of the results in SELECT, then, is that the mean participant judged a protagonist's moral disapproval of a client to be a good reason to refuse representation when participants agreed with the disapproval, and not a good reason to deny representation when participants disagreed with the disapproval. Such a finding is consistent with the affective-primacy hypothesis, and social intuitionist models of moral judgment more generally.

In short, our results do not generally support the hypothesis that participants' judgments about the status of the lawyer's actions were predominated by emotional or affective considerations.

98. In a survey experiment by Jonathan Haidt and colleagues testing the interaction between affective cues and moral judgments, $64 \%$ of participants favored of interference to prevent or punish activity in Kissing item, where brother and sister "find a secret hiding place" to "kiss each other on the mouth, passionately" when "no nobody is around." See Jonathan Haidt, Silvia Helena Koller \& Maria G. Dias, Affect, Culture, and Morality, or Is it Wrong to Eat Your Dog?, 65 J. Pers. \& Soc. Psychol. 613, 617, table 1 (1993). 
